\title{
SYNTHESIS, COMPLEXATION AND BIOLOGICAL ACTIVITY OF NEW ISATIN SCHIFF_BASES
}

\author{
S.A. SALLAM*, E.S.I. IBRAHIM AND M.I. ANWAR \\ Chemistry Department, Faculty of Science, Suez Canal University, Ismailia, Egypt \\ (Received: August 5, 011 - Accepted: January 23, 2012)
}

\begin{abstract}
Some new Schiff-bases derived from condensation of 3-hydrazono-2-oxo-2,3-dihydroindol-1-yl)-acetic acid hydrazide (3) with benzaldehyde, p-methoxybenzaldehyde and p-chlorobenzaldehyde have been synthesized in high yields via refluxing in EtOH in the presence of catalytic amount of acetic acid. The synthesized compounds have been characterized by elemental analysis, IR, ${ }^{\mathrm{H}} \mathrm{H}-\mathrm{NMR}$ and mass spectra. $\mathrm{Cu}$ (II), $\mathrm{Zn}$ (II), $\mathrm{Mn}$ (II) and Fe(III) complexes of the synthesized compounds were prepared and characterized by elemental analysis, conductivity measurements, IR, UV-Vis. spectra and magnetic moment measurements. TGA and DTA confirm the chemical formulation of the complexes and their thermal decomposition were evaluated. Antimicrobial activity of the synthesized compounds have been screened using the desk diffusion method with different strains of bacteria: Staphylococcus aureus, Klebsiella pneumoniae, Escherichia coli and Proteus volgaris were used.
\end{abstract}

Keywords: Isatin Schiff-bases; $\mathrm{Cu}(\mathrm{II}), \mathrm{Zn}(\mathrm{II}), \mathrm{Mn}(\mathrm{II})$ complexes; spectral, thermal properties and biological activity.

\section{INTRODUCTION}

Isatin Schiff-bases are known to possess a wide range of pharmacological properties including antibacterial ${ }^{1-3}$, anticonvulsant ${ }^{4-5}$, anti-HIV ${ }^{6-9}$ antifungal ${ }^{10-13}$ and antiviral activity ${ }^{14}$. Isatin bis-Schiff bases are characterized by their capacity to co-ordinate to metal ions forming chelate rings ${ }^{15}$, act as inhibitors of human $\alpha$-thrombin ${ }^{16}$ and its copper(II) complex catalyzed the oxidation of carbohydrates ${ }^{17}$. Recently it has been reported that isatin bis-imine has antimicrobial properties ${ }^{18}$ and affects cell viability ${ }^{19}$.

We report here the synthesis and characterization of some new Schiffbases derived from the condensation of 3-hydrazono-2-oxo-2,3-dihydroindol-1-yl-acetic acid hydrazide with benzaldehyde, p-methoxybenzaldehyde and p-chlorobenzaldehyde and also their $\mathrm{Cu}(\mathrm{II}), \mathrm{Zn}(\mathrm{II}), \mathrm{Mn}(\mathrm{II})$, and $\mathrm{Fe}(\mathrm{III})$ complexes. Biological activity of the new compounds against strains of bacteria [Staphylococcus aureus, Klebsiella pneumoniae, Escherichia coli and Proteus vulgaris] was also tested.

\section{EXPERIMENTAL}

\section{Materials and methods}

All used solvents and metal salts were of A.R. grade. They were supplied by Merck and BDH and were used as received. All melting points measured on a MEL-TempII melting point apparatus were uncorrected. Thin layer chromatography (TLC) was carried out on aluminum sheets precoated with silica gel mesh 60F 254 of $0.2 \mathrm{~mm}$ thick. Elemental analyses were carried out using a Heraus $\mathrm{CHN}$-rapid analyzer. Infrared spectra were recorded ( $\mathrm{KBr}$ disc) in the $400-4000 \mathrm{~cm}^{-1}$ range on Bruker Vector 22 spectrophotometer. ${ }^{1} \mathrm{H}-\mathrm{NMR}$ measurements were carried out on a Bruker ARX (300 MHz) using $\mathrm{d}_{6}$-DMSO as a solvent and TMS as internal standard. Mass spectral data are measured on Varian MAT-711 mass spectrometer. GC-MS were obtained with model 5988A Hewlet-Packard 5890 spectrometer. Electronic absorption spectra were obtained using $10^{-3} \mathrm{M}$ DMF solutions in $1 \mathrm{~cm}$ quartz cell on UV-1601PC Shimadzu spectrophotometer. Magnetic susceptibility measurements were carried out using the modified Gouy method ${ }^{20}$ on MSB-MK1 balance at room temperature using $\left[\mathrm{HgCo}(\mathrm{SCN})_{4}\right]$ as standard. The effective magnetic moment, $\mu_{\mathrm{eff}}$ per metal atom was calculate from the expression $\mu_{\mathrm{eff}}=2.83 \sqrt{\chi . T}$ B.M., where $\mathcal{X}$ is the molar susceptibility corrected using Pascal's constant for the diamagnetism of all atoms in the complexes. TGA, DTG and DTA were recorded on Shimadzu-60 thermal analyzer under a dynamic flow of nitrogen $\left(30 \mathrm{ml} / \mathrm{min}\right.$.) and heating rate $10^{\circ} \mathrm{C} / \mathrm{min}$. Electrical conductivity measurements were carried out at room temperature on freshly prepared $10^{-3} \mathrm{M}$ DMF solutions using WTW conductivity meter fitted with L100 conductivity cell.

\section{Synthesis}

(2,3-Dioxo-2,3-dihydro-indol-1-yl)acetic acid ethyl ester: (2)

To a stirred solution of isatin (1) $(1.5 \mathrm{~g}, 10.18 \mathrm{mmol})$ in acetone $(35 \mathrm{ml})$, $\mathrm{K}_{2} \mathrm{CO}_{3}(1.4 \mathrm{~g}, 10.18 \mathrm{mmol})$ was added and the mixture was stirred for $1 \mathrm{~h}$. A solution of ethylchloroacetate $(1 \mathrm{ml}, 10.18 \mathrm{mmol})$ in acetone $(15 \mathrm{ml})$ was added dropwise with stirring for $5 \mathrm{~h}$ at room temperature after which the mixture was filtered. The filtrate is concentrated under reduced pressure, the resulting white crystalline precipitate was collected and crystallized from acetonehexane mixture. Yield: $1.1 \mathrm{~g}(69.6 \%)$, m.p. $139-140^{\circ} \mathrm{C}$. Anal.: Calcd. (\%) for $\mathrm{C}_{12} \mathrm{H}_{11} \mathrm{NO}_{4}: \mathrm{C}, 61.80 ; \mathrm{H}, 4.75 ; \mathrm{N}, 6.01$. Found (\%) : C, 61.79; H, 4.77; N, 5.87; IR: $v\left(\mathrm{~cm}^{-1}\right): 1696,1675,1653(\mathrm{C}=\mathrm{O}) ; \mathrm{MS}: \mathrm{M}^{+}(\%)=233(0.08), 205(24), 172$ (6), 162 (53), 160 (36), 148 (49.9), $120(54), 119$ (100), 91 (20).

(3-Hydrazono-2-oxo-2,3-dihydro-indol-1-yl)-acetic acid hydrazide: (3) $80 \%$ Hydrazine hydrate $(4 \mathrm{ml}, 80 \mathrm{mmol})$ was added to a solution of (2) $(1 \mathrm{~g}, 4.3 \mathrm{mmol})$ in EtOH $(15 \mathrm{ml})$ and the mixture was stirred for $4 \mathrm{~h}$ at room temperature and concentrated under reduced pressure. The resulting solid white crystals was filtered off , crystallized from ethyl acetate to give (3). Yield: $0.7 \mathrm{~g}(70 \%)$; m.p. 183-186 ${ }^{\circ} \mathrm{C}$. Anal.: calcd. (\%) for $\mathrm{C}_{10} \mathrm{H}_{11} \mathrm{~N}_{5} \mathrm{O}_{2}: \mathrm{C}$, 51.50, H, 4.75, N, 30.03; found (\%): C, 51.48; H, 4.81; N, 29.98. IR: $v\left(\mathrm{~cm}^{-1}\right)$ : $3525(\mathrm{OH}), 3433,3337(\mathrm{NH}), 1669(\mathrm{C}=\mathrm{O}), 1612(\mathrm{C}=\mathrm{N})$; $\mathrm{MS}:\left(\mathrm{M}^{+} \mathrm{NHNH}_{2}\right)(\%)$ $=202(9.16), 201(72), 170(100), 140(20), 101(38.5) ;{ }^{1} \mathrm{H}-\mathrm{NMR}\left(\mathrm{CDCl}_{3}\right) \delta$ (ppm): 8.02 (d, 1H, H7), 7.88 (d, 1H, H6), 7.6 (m, 1H,H5), 7.5 (m, 1H, H8), $3.54\left(\mathrm{~s}, 5 \mathrm{H}, 2 \mathrm{NH}_{2}, \mathrm{OH}\right), 2.6\left(\mathrm{~s}, 2 \mathrm{H}, \mathrm{CH}_{2}\right)$.

(3-(Benzylidene-hydrazono)-2-oxo-2,3-dihydro-indol-1-yl)-acetic acid benzylidene-hydrazide derivatives: (4-6)

Benzaldehyde or its derivative $(20.0 \mathrm{mmol})$ was added to an acidified (few drops of $\mathrm{CH}_{3} \mathrm{COOH}$ ) stirred solution of (3) $(2.3 \mathrm{~g}, 10.0 \mathrm{mmol}$ ) in EtOH $(20 \mathrm{ml})$. The mixture was heated on a water bath for $2 \mathrm{~h}$, the precipitate was filtered, washed with $\mathrm{EtOH}$ and crystallized from methanol to give the following compounds:

(3-Hydrazono-2-oxo-2,3-dihydro-indol-1-yl)-acetic acid benzylidenehydrazide: $\left(\mathrm{HL}^{1}\right)$

Yield: $85.3 \%$; m.p. $196-198^{\circ} \mathrm{C}$. Anal. : calcd. (\%) for $\mathrm{C}_{17} \mathrm{H}_{15} \mathrm{~N}_{5} \mathrm{O}_{2}$ : C, 63.54; H, 4.71; N, 21.79; found (\%): C, 63.32 H, 4.77; N, 21.69. IR v( $\left.\mathrm{cm}^{-1}\right)$ : $3478(\mathrm{OH}), 3351(\mathrm{NH}), 1657(\mathrm{C}=\mathrm{O}), 1596,1565(\mathrm{C}=\mathrm{N}) ; \mathrm{MS}: \mathrm{M}^{+}(\%)=321$ (0.03), 305 (0.05), 291(0.17), 187 (13.75), 186 (95.36), 170 (87.18); 142 (100); ${ }^{1} \mathrm{H}-\mathrm{NMR} \delta(\mathrm{ppm}): 12.1(\mathrm{~s}, 1 \mathrm{H}, \mathrm{NH}), 8.3(\mathrm{~s}, 1 \mathrm{H}, \mathrm{CH}), 8.0$ - $7.2(\mathrm{~m}, 11 \mathrm{H}, 9 \mathrm{Ar}-$ $\left.\mathrm{H}, \mathrm{NH}_{2}\right), 2.7\left(\mathrm{~s}, 2 \mathrm{H}, \mathrm{CH}_{2}\right)$.

(3-Hydrazono-2-oxo-2,3-dihydro-indol-1-yl)-acetic acid (4-methoxybenzylidene)-hydrazide: $\left(\mathrm{HL}^{2}\right)$

Yield 57\%; m.p. $211-213^{\circ} \mathrm{C}$. Anal.: calcd.(\%) for $\mathrm{C}_{18} \mathrm{H}_{17} \mathrm{~N}_{5} \mathrm{O}_{3}$ : C, $61.53 ; \mathrm{H}$, 4.88; N, 19.93; found (\%): C, 61.51; H, 4.75; N, 19.89. IR $v\left(\mathrm{~cm}^{-1}\right): 3447(\mathrm{OH})$, $3293(\mathrm{NH}), 1650(\mathrm{C}=\mathrm{O}), 1605,1542(\mathrm{C}=\mathrm{N})$; MS: $\left(\mathrm{M}^{+}-\mathrm{OCH}_{3}\right)(\%)=321(0.7)$, 320 (5.72), 319 (24.1), 186 (95.25), 170 (82), 142 (100), 134 (23); ${ }^{1} \mathrm{H}-\mathrm{NMR} \delta$ (ppm): $12.01(\mathrm{~s}, 1 \mathrm{H}, \mathrm{NH}), 8.26(\mathrm{~s}, 1 \mathrm{H}, \mathrm{CH}), 8.11-6.81\left(\mathrm{~m}, 10 \mathrm{H}, 8 \mathrm{Ar}-\mathrm{H}, \mathrm{NH}_{2}\right)$, $3.81\left(\mathrm{~s}, 3 \mathrm{H}, \mathrm{OCH}_{3}\right), 2.71\left(\mathrm{~s}, 2 \mathrm{H}, \mathrm{CH}_{2}\right)$

(3-Hydrazono-2-oxo-2,3-dihydro-indol-1-yl)-acetic acid (4-chlorobenzylidene)-hydrazide: $\left(\mathrm{HL}^{3}\right)$

Yield 75.5\%; m.p. $197-200^{\circ} \mathrm{C}$. Anal.: calcd.(\%) for $\mathrm{C}_{17} \mathrm{H}_{14} \mathrm{ClN}_{5} \mathrm{O}_{2}$ : C, 57.39; H, 3.97; N, 19.68; found (\%): C, 57.37; H, 3.99; N, 19.71. IR $v\left(\mathrm{~cm}^{-}\right.$ 1): $3443(\mathrm{OH}), 3315(\mathrm{NH}), 1669(\mathrm{C}=\mathrm{O}), 1594,1559(\mathrm{C}=\mathrm{N}), \mathrm{MS}:(\mathrm{M}+2)^{+}(\%)$ $=357.15(0.07), \mathrm{M}^{+}(\%)=355.5(0.25), 325(2.7), 186(85), 170(100), 142$ (84.6), 101 (27.6); ${ }^{1} \mathrm{H}-\mathrm{NMR} \delta$ (ppm): $12.16(\mathrm{~s}, 1 \mathrm{H}, \mathrm{NH}), 8.35$ (s, $\left.1 \mathrm{H}, \mathrm{CH}\right)$, 8.14-7.1 ( $\mathrm{m}, 10 \mathrm{H}\left(8 \mathrm{Ar}-\mathrm{H}, \mathrm{NH}_{2}\right), 2.72\left(\mathrm{~s}, 2 \mathrm{H}, \mathrm{CH}_{2}\right)$.

Synthesis of the complexes

To a solution of the Schiff-base $(2 \mathrm{mmol})$ in EtOH $(10 \mathrm{ml})$, a solution of 
the metal salt $(1 \mathrm{mmol})$ in ethanol $(10 \mathrm{ml})$ was added dropwise with stirring. The $\mathrm{pH}$ of the mixture was increased to $7-7.5$ by addition of dilute $\mathrm{KOH}$ solution. The whole mixture is refluxed with stirring for 2 hours. The formed precipitate was filtered, washed with hot $\mathrm{EtOH}$ and dried under vacuum over anhydrous $\mathrm{CaCl}_{2}$. Since the complexes were insoluble and non crystallizable in common organic solvents, they were purified by washing thoroughly with hot ethanol to remove unreacted metal salts.

\section{Growth media}

Nutrient agar medium of the following composition peptone $5.0 \mathrm{~g}$, beef extract $3.0 \mathrm{~g}, \mathrm{NaCl} 5.0 \mathrm{~g}$, agar $18.0 \mathrm{~g}$ and $1000 \mathrm{ml}$ water has been used for growing test organisms. The prepared media was poured into $9 \mathrm{~cm}$ plates and allowed to solidify. Spore suspensions from actively growing cultures were prepared using sterile distilled water. One $\mathrm{ml}$ of spore suspension was transferred to these plates and incubated at $37^{\circ} \mathrm{C}$ for appropriate growth periods (1-3 days). 100 ppm of the tested compound was dissolved in DMF, while DMF itself was used as control for comparison. The diameters of cleaning zones (in $\mathrm{mm}$ ) have been used as a parameter for antibacterial activity. Accordingly, the resulting effects have been tentatively classified as follows: slightly active (1$10 \mathrm{~mm})$; moderately active $(11-20 \mathrm{~mm})$; highly active $(20-30 \mathrm{~mm})$ and very highly active ( $>30 \mathrm{~mm})$.. Streptomycin was used as standard.

\section{RESULTS AND DISCUSSION}

\section{Characterization of the Schiff-bases}

Reaction of isatin (1) with ethyl chloroacetate afforded 2,3-dioxo-2,3dihydroindol-1-yl acetic acid ethyl ester (2) which upon reaction with hydrazine hydrate in presence of acetic acid gave 3-hydrazono-2-oxo-2,3-dihydroindole1-ylacetic acid hydrazide (3). On heating (3) with each of benzaldehyde, anisaldehyde and p-chlorobenzaldehyde in ethanol containing few drops of acetic acid afforded the Schiff-bases $\mathrm{HL}^{1}-\mathrm{HL}^{3}$ respectively (Scheme 1)
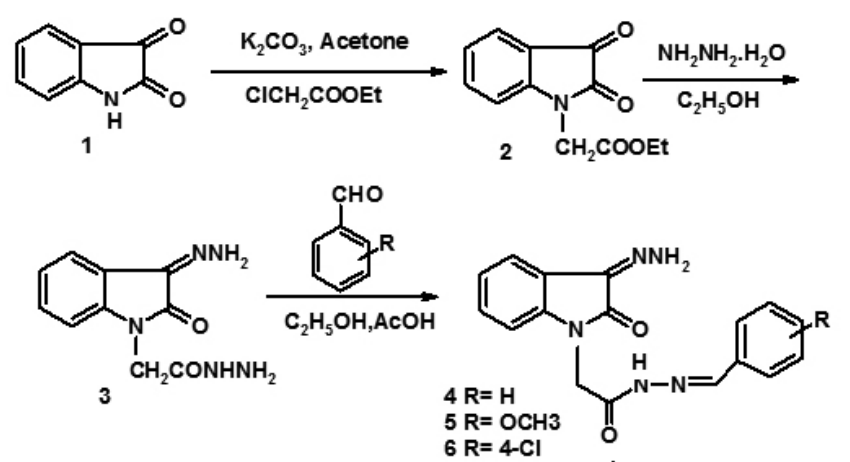

Schem e (1)

Compound (3) shows three absorption bands at 3525, 3433 and $3337 \mathrm{~cm}^{-1}$ due to the hydrazide and hydrazone groups. This structure was also confirmed by the ${ }^{1} \mathrm{H}$-NMR spectra which showed the presence of a broad singlet at $\delta 3.54$ ppm assigned to the hydrazide and hydrazone groups together with two duplets and three triplets in the $\delta 8.03-7.41 \mathrm{ppm}$ range attributed to the four aromatic protons besides a singlet at $\delta 2.6 \mathrm{ppm}$ due to the methylene protons. Mass spectrum of compound (3) shows that it losses a hydrazine molecule to give the ketene radical cation with $\mathrm{m} / \mathrm{z}=201$.IR spectrum of (2) shows three absorption bands at 1696,1675 and $1653 \mathrm{~cm}^{-1}$ assigned to the frequency of the carbonyl groups. Mass spectrum of compound (2) showed the expected $\mathrm{m} / \mathrm{z}=233$ which losses the ethyl radical to give the cation with $\mathrm{m} / \mathrm{z}=205$.

IR spectra of the Schiff-bases $\mathrm{HL}^{1}-\mathrm{HL}^{3}$ showed a sharp medium intensity band in the $3443-3478 \mathrm{~cm}^{-1}$ range assigned to stretching vibration of the $(\mathrm{OH})$ group and disappearance of $(\mathrm{NH})$ and amide $(\mathrm{C}=\mathrm{O})$ bands due to enolization. These considerations suggest that the ligand has keto-enol tautomerism and exist primarily in the enol form. The spectra exhibit a characteristic splitted band in the 3266-3351 $\mathrm{cm}^{-1}$ range which is assigned to $v\left(\mathrm{NH}_{2}\right)$ in addition to strong intensity band in the $750-765 \mathrm{~cm}^{-1}$ range due to wagging vibration. A strong band appeared at $1669-1650 \mathrm{~cm}^{-1}$ range is due to the isatin $v(\mathrm{C}=\mathrm{O})$ group. Two bands are shown in the 1605-1594 and 1565-1542 $\mathrm{cm}^{-1}$ range which have been assigned as $\mathrm{v}(\mathrm{C}=\mathrm{N})$ of ketimine and aldimine moieties. ${ }^{1} \mathrm{H}-\mathrm{NMR}$ spectra showed signals attributed to the $\mathrm{CH}_{2}, \mathrm{Ar}-\mathrm{H}, \mathrm{NH}_{2}, \mathrm{CH}$, and the NH. 'H-NMR of compound (5) showed in addition to the previous signals a new singlet at $\delta 3.81 \mathrm{ppm}$ assigned to the $\mathrm{OCH}_{3}$ protons . Mass spectra confirm the proposed structures of compounds (4-6).

\section{Metal complexes}

All the complexes are stable at room temperature and non-hygroscopic in nature. The stoichiometric ratios of the complexes have been calculated from their elemental analysis. The complexes are insoluble in water and common organic solvents (methanol, ethanol, benzene, chloroform, acetone, dichloroethane and diethyl ether) but soluble in DMSO and DMF. The analytical data (Table 1) show the following formulae for the complexes: $\left[\mathrm{Cu}\left(\mathrm{HL}^{1-3}\right)_{2}\right] \cdot\left(\mathrm{NO}_{3}\right)_{2} \cdot \mathrm{nH}_{2} \mathrm{O}$ where $\mathrm{n}=5,11 / 2,0 ;\left[\mathrm{Fe}_{2}\left(\mathrm{~L}^{1-3}\right)\left(\mathrm{NO}_{3}\right)_{\mathbf{x}}\left(\mathrm{H}_{2} \mathrm{O}\right)_{2}\right] .\left(\mathrm{NO}_{3}\right)$ . $\mathrm{nH}_{2} \mathrm{O}$ where $\mathrm{x}=5,5,3 ; \mathrm{z}=0,0,2 ; \mathrm{n}=4,1,2$ and $\left[\mathrm{M}_{2}\left(\mathrm{~L}^{1-3}\right)\left(\mathrm{H}_{2} \mathrm{O}\right)_{4}\right] .\left(\mathrm{NO}_{3}\right)_{3} \cdot \mathrm{nH}_{2} \mathrm{O}$ where $\mathrm{M}=\mathrm{Zn}(\mathrm{II})$ and $\mathrm{Mn}(\mathrm{II})$ and $\mathrm{n}=1,1 ; 1 / 2,1 \frac{1}{2} ; 1,3$. The molar conductance values in DMF show that the $\mathrm{Cu}(\mathrm{II})$ complexes are 1:2 electrolytes, the $\mathrm{Fe}(\mathrm{III})$ complexes are none-electrolytes except $\left[\mathrm{Fe}_{2}\left(\mathrm{~L}^{3}\right)\left(\mathrm{NO}_{3}\right)_{3}\left(\mathrm{H}_{2} \mathrm{O}\right)_{2}\right] \cdot\left(\mathrm{NO}_{3}\right)_{2} \cdot 2 \mathrm{H}_{2} \mathrm{O}$ which is $1: 2$ electrolyte, the $\mathrm{Zn}$ (II) and $\mathrm{Mn}$ (II) complexes are 1:3 electrolytes. ${ }^{21}$

\section{IR Spectra}

Some structurally significant IR bands of the free Schiff-bases and their transition metal complexes are set out in Table 2.

The IR spectra of the $\mathrm{Cu}(\mathrm{II}), \mathrm{Fe}(\mathrm{III}), \mathrm{Zn}$ (II) and $\mathrm{Mn}(\mathrm{II})$ complexes show the absence of $v\left(\mathrm{NH}_{2}\right)$ band due to overlapping with crystallization water band while the band due to wagging vibration is shifted to lower frequency indicating coordination through the amino nitrogen atom. A slight shift with decreasing intensity of isatin $v(\mathrm{C}=\mathrm{O})$ band confirms involvement of the carbonyl oxygen in complexation. The disappearance of $v(\mathrm{OH})$ band in the spectra of the complexes indicates deprotonation and participation in coordination with metal ions. On the other hand, for the $\mathrm{Cu}(\mathrm{II})$ complexes the $(\mathrm{OH})$ band is disappeared due to overlapping with hydrated water band, and the deformation band $\delta(\mathrm{OH})$ at $1250 \mathrm{~cm}^{-1}$ almost has the same frequency as in the free ligand indicating noninvolvement of the $\mathrm{OH}$ group in coordination. The shifting in $\mathrm{v}(\mathrm{C}=\mathrm{N})$ band of the aldimine moiety can be attributed to involvement in bonding while $v(\mathrm{C}=\mathrm{N})$ of the ketimine moiety appeared nearly at the same frequency as the parent ligand indicating non-participating in bonding. The presence of coordinated nitrate ions are indicated by two medium intensity bands at 1450, 1358 and $1432,1302 \mathrm{~cm}^{-1}$ in the $\left[\mathrm{Fe}_{2} \mathrm{~L}^{1}\left(\mathrm{NO}_{3}\right)_{5}\left(\mathrm{H}_{2} \mathrm{O}\right)_{2}\right] .4 \mathrm{H}_{2} \mathrm{O}$ and $\left[\mathrm{Fe}_{2} \mathrm{~L}^{2}\left(\mathrm{NO}_{3}\right)_{5}\left(\mathrm{H}_{2} \mathrm{O}\right)_{2}\right]$. $\mathrm{H}_{2} \mathrm{O}$ complexes due to $v_{4}$ and $v_{1}$ vibrations of the nitrate ion of $\mathrm{C}_{2 \mathrm{v}}$ Symmetry ${ }^{22}$. Since $\left(v_{4}-v_{1}\right)=92$ and $130 \mathrm{~cm}^{-1}$, the nitrate ions are coordinated as unidentate group. These two complexes also exhibit bands due to bidentate nitrate groups which show bands at 1506, 1292 and $1501,1285 \mathrm{~cm}^{-1}$ with $\left(v_{4}-v_{1}\right)=214$ and $216 \mathrm{~cm}^{-1}$. This is emphasized by the molar conductance of the complexes which have values of 40 and $45 \mathrm{ohm}^{-1} \cdot \mathrm{cm}^{2} \cdot \mathrm{mol}^{-1}$ of $10^{-3} \mathrm{M}$ DMF solution, indicating its non-electrolytic nature and hence the nitrate ions are coordinated to the metal center. The IR spectrum of $\left[\mathrm{Fe}_{2} \mathrm{~L}^{3}\left(\mathrm{NO}_{3}\right)_{3}\left(\mathrm{H}_{2} \mathrm{O}\right)_{2}\right] \cdot\left(\mathrm{NO}_{3}\right)_{2} \cdot 2 \mathrm{H}_{2} \mathrm{O}$ shows bands due to bidentate nitrate groups at 1500 and $1281 \mathrm{~cm}^{-1}$ where $\left(v_{4}\right.$ $\left.v_{1}\right)=219 \mathrm{~cm}^{-1}$ together with strong and a medium intensity bands at 1381 and $855 \mathrm{~cm}^{-1}$ due to the $v_{3}$ and $v_{2}$ vibrations of the ionic nitrate $\left(\mathrm{D}_{33}\right)^{22}$. The $\mathrm{Cu}(\mathrm{II})$, $\mathrm{Zn}(\mathrm{II})$ and $\mathrm{Mn}$ (II) complexes show strong bands in the $1367-1384 \mathrm{~cm}^{-1}$ range and medium intensity bands in the $837-863 \mathrm{~cm}^{-1}$ range, due to the $v_{3}$ and $v_{2}$ vibrations of the ionic nitrate $\left(\mathrm{D}_{3}\right)^{23}$. A non ligand bands appear in the 515-612 and 413-515 $\mathrm{cm}^{-1}$ range in all the complexes have been assigned to $v(\mathrm{M}-\mathrm{O})$ and $v(\mathrm{M}-\mathrm{N})^{24}$. Water of crystallization is shown by a medium intensity broad band in the $3373-3525 \mathrm{~cm}^{-1}$ range in the spectra of the complexes.

\section{Magnetic and spectral studies}

Magnetic moments and visible spectra of the complexes were used to study the geometrical configuration of the metal complexes.

The magnetic moment values for the zinc(II) complexes are zero consistent with its $\mathrm{d}^{10}$ configuration. Copper(II) complexes show magnetic moment values in the 2.0-1.97 B.M. range which are close to spin only value. This range indicates the absence of any appreciable spin-spin coupling between unpaired electrons belonging to different molecules. According to Figgis ${ }^{25}$, a magnetic moment value greater than 1.9 B.M. indicates tetrahedral or octahedral 
stereochemistry, while magnetic moment value less than 1.9 B.M. is indicative of square planer as well as tetrahedral stereochemistry. This shows that the magnetic moment of the $\mathrm{Cu}$ (II) complexes is not of much use in deciding on the stereochemistry of copper(II) complex.

The magnetic moments reported for the Fe(III) and Mn(II) complexes are lower than the spin only values. The subnormal magnetic moments observed for the complexes may be accounted for by the following:

a- Antiferromagnetic exchange interaction between the metal ions, suggesting the possibility of spin-spin coupling ${ }^{26,27}$.

b- The possibility that the reduced moment represent a solid state intermolecular interaction rather than an intramolecular coupling.

These considerations confirm the binuclear structure of the complexes. Such lowering of the magnetic moment has been observed with other polynuclear complexes ${ }^{28}$.
Electronic spectra of the Schiff-bases and their complexes are recorded in DMF. The copper(II) complexes show a broad band in the 625-665 range which can be assigned to ${ }^{2} \mathrm{E}_{\mathrm{g}} \rightarrow{ }^{2} \mathrm{~T}_{2 \mathrm{~g}}$ transition of copper(II) ion with octahedral geometry ${ }^{29}$. The spectra of the Fe(III) complexes exhibit a band in the 516-485 $\mathrm{nm}$ range corresponding to ${ }^{6} \mathrm{~A}_{1 \mathrm{~g}} \rightarrow{ }^{4} \mathrm{~T}_{1 \mathrm{~g}}$ transition consistent with octahedral $\mathrm{Fe}(\mathrm{III})$ complexes ${ }^{29,30}$. The electronic spectra of the low-spin manganese complex is dominated by strong charge-transfer bands. Any d-d band occurring in the visible region is masked by strong charge-transfer bands.

\section{Thermal Decomposition}

Thermal decomposition of the complexes studied in these work represents characteristic pathways depending on the metal used as can be seen from the TGA/DTG and DTA curves shown in Figures 1 and 2. The decomposition stages, temperature ranges, decomposition products, as well as the found and calculated weight loss are given in Tables 3 and 4.

Table 1: Analytical data, conductivity values and magnetic moments of the Schiff-bases and their complexes.

\begin{tabular}{|c|c|c|c|c|c|c|c|c|c|c|}
\hline \multirow[t]{2}{*}{ Comopound } & \multirow[t]{2}{*}{ M.wt. } & \multirow[t]{2}{*}{ Color } & \multirow[t]{2}{*}{$\begin{array}{l}\text { M.p. } \\
{ }^{\circ} \mathrm{C} .\end{array}$} & \multirow[t]{2}{*}{$\begin{array}{l}\text { Yield } \\
\%\end{array}$} & \multicolumn{4}{|c|}{$\begin{array}{c}\text { Elemental analysis } \\
\text { Found } \\
\text { Calcd. } \% \\
\end{array}$} & \multirow[t]{2}{*}{${ }^{{ }^{*} \Lambda_{\mathrm{M}}}$} & \multirow[t]{2}{*}{${ }^{* *} \mu_{\mathrm{eff}} / \mathrm{M}$} \\
\hline & & & & & $\mathrm{C}$ & $\mathrm{H}$ & $\mathrm{N}$ & M & & \\
\hline $\mathrm{HL}^{1}$ & 320.82 & yellow & 198 & 85.3 & $\begin{array}{l}63.49 \\
63.58\end{array}$ & $\begin{array}{l}4.51 \\
4.67\end{array}$ & $\begin{array}{l}21.91 \\
21.81\end{array}$ & - & - & - \\
\hline$\left[\mathrm{Cu}\left(\mathrm{H} \mathrm{L}_{2}^{1}\right)\right] .\left(\mathrm{NO}_{3}\right)_{2} \cdot 5 \mathrm{H}_{2} \mathrm{O}$ & 918.48 & green & $>380$ & 72.3 & $\begin{array}{l}44.31 \\
44.36\end{array}$ & $\begin{array}{l}4.09 \\
4.34\end{array}$ & $\begin{array}{l}18.31 \\
18.27\end{array}$ & $\begin{array}{l}7.35 \\
6.91\end{array}$ & 130 & 2.0 \\
\hline$\left[\mathrm{Fe}_{2} \mathrm{~L}^{1}\left(\mathrm{NO}_{3}\right)_{5}\left(\mathrm{H}_{2} \mathrm{O}\right)_{2}\right] \cdot 4 \mathrm{H}_{2} \mathrm{O}$ & 849.35 & brown & $>380$ & 63.2 & $\begin{array}{l}24.23 \\
24.01\end{array}$ & $\begin{array}{l}3.44 \\
3.17\end{array}$ & $\begin{array}{l}16.53 \\
16.48\end{array}$ & $\begin{array}{l}13.51 \\
13.14\end{array}$ & 40 & 2.72 \\
\hline$\left[\mathrm{Zn}_{2} \mathrm{~L}^{1}\left(\mathrm{H}_{2} \mathrm{O}\right)_{4}\right] \cdot\left(\mathrm{NO}_{3}\right)_{3} \cdot \mathrm{H}_{2} \mathrm{O}$ & 726.51 & yellow & $>380$ & 51.66 & $\begin{array}{l}27.93 \\
28.07\end{array}$ & $\begin{array}{l}3.55 \\
3.44\end{array}$ & $\begin{array}{l}15.76 \\
15.41\end{array}$ & $\begin{array}{l}18.43 \\
18.00\end{array}$ & 207 & Dia. \\
\hline$\left[\mathrm{Mn}_{2} \mathrm{~L}^{1}\left(\mathrm{H}_{2} \mathrm{O}\right)_{4}\right] \cdot\left(\mathrm{NO}_{3}\right)_{3} \cdot \mathrm{H}_{2} \mathrm{O}$ & 705.60 & brown & $>380$ & 52.55 & $\begin{array}{l}28.87 \\
28.91\end{array}$ & $\begin{array}{l}3.63 \\
3.54\end{array}$ & $\begin{array}{l}15.92 \\
15.87\end{array}$ & $\begin{array}{l}15.48 \\
15.57\end{array}$ & 220 & 3.09 \\
\hline $\mathrm{HL}^{2}$ & 350.82 & white & 213 & 57 & $\begin{array}{l}61.49 \\
61.56\end{array}$ & $\begin{array}{l}4.77 \\
4.84\end{array}$ & $\begin{array}{l}19.91 \\
19.95\end{array}$ & - & - & - \\
\hline$\left[\mathrm{Cu}\left(\mathrm{H} \mathrm{L}_{2}^{2}\right)\right] \cdot\left(\mathrm{NO}_{3}\right)_{2} \cdot 1 \frac{1}{2} \mathrm{H}_{2} \mathrm{O}$ & 916.12 & green & 196 & 79.65 & $\begin{array}{l}47.21 \\
47.13\end{array}$ & $\begin{array}{l}4.12 \\
4.03\end{array}$ & $\begin{array}{l}18.11 \\
18.33\end{array}$ & $\begin{array}{l}7.42 \\
6.93\end{array}$ & 140 & 1.97 \\
\hline$\left[\mathrm{Fe}_{2} \mathrm{~L}^{2}\left(\mathrm{NO}_{3}\right)_{5}\left(\mathrm{H}_{2} \mathrm{O}\right)_{2}\right] \cdot \mathrm{H}_{2} \mathrm{O}$ & 825.35 & brown & 220 & 64.22 & $\begin{array}{l}26.36 \\
26.17\end{array}$ & $\begin{array}{l}2.69 \\
2.78\end{array}$ & $\begin{array}{l}16.73 \\
16.96\end{array}$ & $\begin{array}{l}13.53 \\
13.95\end{array}$ & 45 & 1.69 \\
\hline$\left[\mathrm{Zn}_{2} \mathrm{~L}^{2}\left(\mathrm{H}_{2} \mathrm{O}\right)_{4}\right] \cdot\left(\mathrm{NO}_{3}\right)_{3} \cdot 1 / 2 \mathrm{H}_{2} \mathrm{O}$ & 747.51 & yellow & 296 & 52.65 & $\begin{array}{l}28.83 \\
28.89\end{array}$ & $\begin{array}{l}3.11 \\
3.47\end{array}$ & $\begin{array}{l}14.61 \\
14.98\end{array}$ & $\begin{array}{l}17.81 \\
17.49\end{array}$ & 220 & Dia. \\
\hline$\left[\mathrm{Mn}_{2} \mathrm{~L}^{2}\left(\mathrm{H}_{2} \mathrm{O}\right)_{4}\right] \cdot\left(\mathrm{NO}_{3}\right)_{3} \cdot 1 \frac{1}{2} \mathrm{H}_{2} \mathrm{O}$ & 744.6 & brown & $>380$ & 51.32 & $\begin{array}{l}29.11 \\
29.00\end{array}$ & $\begin{array}{l}3.63 \\
3.75\end{array}$ & $\begin{array}{l}15.31 \\
15.04\end{array}$ & $\begin{array}{l}14.91 \\
14.75\end{array}$ & 225 & 2.11 \\
\hline $\mathrm{HL}^{3}$ & 355.32 & white & 200 & 75.5 & $\begin{array}{l}57.48 \\
57.40\end{array}$ & $\begin{array}{l}3.81 \\
3.93\end{array}$ & $\begin{array}{c}19.67 \\
19.7\end{array}$ & - & - & - \\
\hline$\left[\mathrm{Cu}\left(\mathrm{H} \mathrm{L}_{2}^{3}\right)\right] .\left(\mathrm{NO}_{3}\right)_{2}$ & 897.48 & green & 245 & 78.32 & $\begin{array}{l}44.47 \\
44.51\end{array}$ & $\begin{array}{l}3.31 \\
3.27\end{array}$ & $\begin{array}{l}18.01 \\
18.33\end{array}$ & $\begin{array}{c}6.8 \\
7.07\end{array}$ & 115 & 1.97 \\
\hline $\begin{array}{c}{\left[\mathrm{Fe}_{2} \mathrm{~L}^{3}\left(\mathrm{NO}_{3}\right)_{3}\left(\mathrm{H}_{2} \mathrm{O}\right)_{2}\right] \cdot\left(\mathrm{NO}_{3}\right)_{2}} \\
2 \mathrm{H}_{2} \mathrm{O}\end{array}$ & 847.85 & brown & 305 & 68.26 & $\begin{array}{l}24.23 \\
24.06\end{array}$ & $\begin{array}{l}2.38 \\
2.59\end{array}$ & $\begin{array}{l}16.86 \\
16.51\end{array}$ & $\begin{array}{l}13.45 \\
13.17\end{array}$ & 145 & 1.66 \\
\hline$\left[\mathrm{Zn}_{2} \mathrm{~L}^{3}\left(\mathrm{H}_{2} \mathrm{O}\right)_{4}\right] \cdot\left(\mathrm{NO}_{3}\right)_{3} \cdot \mathrm{H}_{2} \mathrm{O}$ & 761.01 & yellow & $>380$ & 53.22 & $\begin{array}{l}26.92 \\
26.80\end{array}$ & $\begin{array}{l}2.98 \\
3.15\end{array}$ & $\begin{array}{l}14.83 \\
14.71\end{array}$ & $\begin{array}{l}17.23 \\
17.18\end{array}$ & 207 & Dia. \\
\hline$\left[\mathrm{Mn}_{2} \mathrm{~L}^{3}\left(\mathrm{H}_{2} \mathrm{O}\right)_{4}\right] \cdot\left(\mathrm{NO}_{3}\right)_{3} \cdot 3 \mathrm{H}_{2} \mathrm{O}$ & 776.10 & brown & $>380$ & 56.21 & $\begin{array}{l}26.35 \\
26.28\end{array}$ & $\begin{array}{l}3.73 \\
3.60\end{array}$ & $\begin{array}{l}14.52 \\
14.43\end{array}$ & $\begin{array}{l}13.97 \\
14.15\end{array}$ & 205 & 3.17 \\
\hline
\end{tabular}

* Conductance of $10^{-3} \mathrm{M}\left(\mathrm{ohm}^{-1} . \mathrm{cm}^{2} \cdot \mathrm{mol}^{-1}\right)$

** $\mu_{\text {eff }}$ at T $=298^{\circ}$ K B.M. 
Table 2: IR spectral data of the Schiff-bases and its complexes.

\begin{tabular}{|c|c|c|c|c|c|c|}
\hline Compound & $\begin{array}{l}v \mathrm{H}_{2} \mathrm{O} \\
v \mathrm{OH} \\
v \mathrm{NH}_{2}\end{array}$ & $v(\mathrm{C}=\mathrm{O})$ & $v(\mathrm{C}=\mathrm{N})$ & $v\left(\mathrm{NO}_{3}\right)$ & $v(\mathrm{M}-\mathrm{O})$ & $v(\mathrm{M}-\mathrm{N})$ \\
\hline $\mathrm{HL}^{1}$ & $\begin{array}{c}- \\
3478 \mathrm{~s} . \\
3351 \mathrm{~s} . \\
3266\end{array}$ & $1657 \mathrm{~s}$ & $\begin{array}{l}1596 \mathrm{~s} . \\
1565 \mathrm{~s} .\end{array}$ & - & - & - \\
\hline$\left[\mathrm{Cu}\left(\mathrm{H} \mathrm{L}_{2}^{1}\right)\right] \cdot\left(\mathrm{NO}_{3}\right)_{2} \cdot 5 \mathrm{H}_{2} \mathrm{O}$ & $3423 \mathrm{br}$. & $1645 \mathrm{~m}$. & $\begin{array}{l}1596 \mathrm{~s} . \\
1539 \mathrm{~s} .\end{array}$ & $\begin{array}{l}1383 \mathrm{~s} . \\
863 \mathrm{~m} .\end{array}$ & $532 \mathrm{~m}$. & $500 \mathrm{~m}$. \\
\hline$\left[\mathrm{Fe}_{2} \mathrm{~L}^{1}\left(\mathrm{NO}_{3}\right)_{5}\left(\mathrm{H}_{2} \mathrm{O}\right)_{2}\right] \cdot 4 \mathrm{H}_{2} \mathrm{O}$ & 3373 br. & $1647 \mathrm{~m}$. & $\begin{array}{l}1603 \mathrm{~s} . \\
1550 \mathrm{~m} .\end{array}$ & $\begin{array}{l}1506 \mathrm{~m} . \\
1450 \mathrm{~m} . \\
1358 \mathrm{~m} . \\
1292 \mathrm{~m} .\end{array}$ & $612 \mathrm{~m}$. & $479 \mathrm{~m}$. \\
\hline$\left[\mathrm{Zn}_{2} \mathrm{~L}^{1}\left(\mathrm{H}_{2} \mathrm{O}\right)_{4}\right] \cdot\left(\mathrm{NO}_{3}\right)_{3} \cdot \mathrm{H}_{2} \mathrm{O}$ & $3423 \mathrm{br}$. & $1638 \mathrm{~m}$. & $\begin{array}{l}1595 \mathrm{~s} . \\
1574 \mathrm{~m} .\end{array}$ & $\begin{array}{l}1380 \mathrm{~s} . \\
837 \mathrm{~m} .\end{array}$ & $602 \mathrm{~m}$ & $474 \mathrm{br}$. \\
\hline$\left[\mathrm{Mn}_{2} \mathrm{~L}^{1}\left(\mathrm{H}_{2} \mathrm{O}\right)_{4}\right] \cdot\left(\mathrm{NO}_{3}\right)_{3} \cdot \mathrm{H}_{2} \mathrm{O}$ & $3422 \mathrm{br}$. & $1641 \mathrm{~m}$. & $\begin{array}{l}1596 \mathrm{~s} . \\
1549 \mathrm{~m} .\end{array}$ & $\begin{array}{l}1382 \mathrm{~s} . \\
860 \mathrm{~m} .\end{array}$ & $518 \mathrm{~m}$. & $429 \mathrm{~m}$. \\
\hline $\mathrm{HL}^{2}$ & $\begin{array}{c}- \\
3447 \mathrm{br} . \\
3293 \mathrm{~s} . \\
3200\end{array}$ & $1650 \mathrm{~s}$. & $\begin{array}{l}1605 \mathrm{~s} . \\
1542 \mathrm{~m} .\end{array}$ & - & - & - \\
\hline$\left[\mathrm{Cu}\left(\mathrm{H} \mathrm{L}_{2}^{2}\right)\right] \cdot\left(\mathrm{NO}_{3}\right)_{2} \cdot 1 \frac{1}{2} \mathrm{H}_{2} \mathrm{O}$ & $\begin{array}{l}3525 \mathrm{br} . \\
3445 \mathrm{br}\end{array}$ & $1662 \mathrm{~m}$. & $\begin{array}{l}1600 \mathrm{~s} . \\
1530 \mathrm{~m} .\end{array}$ & $\begin{array}{l}1383 \mathrm{~s} . \\
863 \mathrm{~m} . .\end{array}$ & $550 \mathrm{~m}$. & $505 \mathrm{~m}$. \\
\hline$\left[\mathrm{Fe}_{2} \mathrm{~L}^{2}\left(\mathrm{NO}_{3}\right)_{5}\left(\mathrm{H}_{2} \mathrm{O}\right)_{2}\right] \cdot \mathrm{H}_{2} \mathrm{O}$ & $3418 \mathrm{br}$. & $1668 \mathrm{~m}$. & $\begin{array}{l}1600 \mathrm{~m} . \\
1529 \mathrm{~m} .\end{array}$ & $\begin{array}{l}1501 \mathrm{~m} . \\
1432 \mathrm{~m} . \\
1302 \mathrm{~m} . \\
1285 \mathrm{~m} .\end{array}$ & $526 \mathrm{~m}$. & $481 \mathrm{~m}$. \\
\hline$\left[\mathrm{Zn}_{2} \mathrm{~L}^{2}\left(\mathrm{H}_{2} \mathrm{O}\right)_{4}\right] \cdot\left(\mathrm{NO}_{3}\right)_{3} \cdot{ }^{1} / 2 \mathrm{H}_{2} \mathrm{O}$ & 3428 br. & $1670 \mathrm{~m}$. & $\begin{array}{l}1601 \mathrm{~m} . \\
1521 \mathrm{~m} .\end{array}$ & $\begin{array}{l}1383 \mathrm{~s} . \\
845 \mathrm{~m} .\end{array}$ & $522 \mathrm{~m}$. & $462 \mathrm{br}$. \\
\hline$\left[\mathrm{Mn}_{2} \mathrm{~L}^{2}\left(\mathrm{H}_{2} \mathrm{O}\right)_{4}\right] \cdot\left(\mathrm{NO}_{3}\right)_{3} \cdot 1 \frac{1}{2} \mathrm{H}_{2} \mathrm{O}$ & $3423 \mathrm{br}$. & $1633 \mathrm{~m}$. & $\begin{array}{l}1601 \mathrm{~m} . \\
1522 \mathrm{~m} .\end{array}$ & $\begin{array}{l}1382 \mathrm{~s} . \\
860 \mathrm{~m} .\end{array}$ & $519 \mathrm{br}$. & 515 br. \\
\hline $\mathrm{HL}^{3}$ & $\begin{array}{c}- \\
3443 \mathrm{~s} . \\
3315 \mathrm{~s} . \\
3283\end{array}$ & $1669 \mathrm{~s}$. & $\begin{array}{l}1594 \mathrm{~s} \\
1559 \mathrm{~s}\end{array}$ & - & - & - \\
\hline$\left[\mathrm{Cu}\left(\mathrm{H} \mathrm{L}_{2}^{3}\right)\right] \cdot\left(\mathrm{NO}_{3}\right)_{2}$ & $\overline{-}$ & $1654 \mathrm{~m}$. & $\begin{array}{l}1592 \mathrm{~m} . \\
1540 \mathrm{~s} .\end{array}$ & $\begin{array}{c}1384 \mathrm{~s} \\
860\end{array}$ & $533 \mathrm{~m}$. & $413 \mathrm{~m}$. \\
\hline$\left[\mathrm{Fe}_{2} \mathrm{~L}^{3}\left(\mathrm{NO}_{3}\right)_{3}\left(\mathrm{H}_{2} \mathrm{O}\right)_{2}\right] \cdot\left(\mathrm{NO}_{3}\right) \cdot 2 \mathrm{H}_{2} \mathrm{O}$ & $3439 \mathrm{br}$. & $1652 \mathrm{~m}$. & $\begin{array}{l}1592 \mathrm{~m} . \\
1541 \mathrm{~m} .\end{array}$ & $\begin{array}{c}1500 \mathrm{~m} . \\
1381 \mathrm{~s} . \\
1281 \mathrm{~m} . \\
855 \mathrm{~m} .\end{array}$ & $515 \mathrm{~m}$. & $467 \mathrm{~m}$. \\
\hline$\left[\mathrm{Zn}_{2} \mathrm{~L}^{3}\left(\mathrm{H}_{2} \mathrm{O}\right)_{4}\right] \cdot\left(\mathrm{NO}_{3}\right)_{3} \cdot \mathrm{H}_{2} \mathrm{O}$ & $3428 \mathrm{br}$. & $1650 \mathrm{~s}$. & $\begin{array}{l}1600 \mathrm{~s} . \\
1543 \mathrm{~m}\end{array}$ & $\begin{array}{l}1367 \mathrm{~s} . \\
837 \mathrm{~m} .\end{array}$ & $533 \mathrm{~m}$ & $467 \mathrm{~m}$. \\
\hline$\left[\mathrm{Mn}_{2} \mathrm{~L}^{3}\left(\mathrm{H}_{2} \mathrm{O}\right)_{4}\right] \cdot\left(\mathrm{NO}_{3}\right)_{3} \cdot 3 \mathrm{H}_{2} \mathrm{O}$ & 3419br. & $1650 \mathrm{~m}$. & $\begin{array}{l}1599 \mathrm{~m} . \\
1538 \mathrm{~m} .\end{array}$ & $\begin{array}{l}1383 \mathrm{~s} . \\
855 \mathrm{~m} .\end{array}$ & $526 \mathrm{~m}$. & $450 \mathrm{~m}$. \\
\hline
\end{tabular}

$\mathrm{m}=$ medium, $\mathrm{s}=$ strong, br=broad

$\mathrm{HL}^{1}$ decomposes in three steps. The first step takes place in the $95-140^{\circ} \mathrm{C}$ range with DTG maximum at $124^{\circ} \mathrm{C}$ associated with weight loss of $5.25 \%$ (calcd. 4.98\%), which represents the elimination of $\mathrm{NH}_{3}$ molecule. This step is confirmed by endothermic DTA change in the $100-140^{\circ} \mathrm{C}$ range with maximum at $124^{\circ} \mathrm{C}$. Melting of this Schiff-base is shown by a sharp endothermic peak at $203^{\circ} \mathrm{C}$. In the second step the ligand continue decomposition to lose $\mathrm{CH}_{2} \mathrm{CONHNCHC} \mathrm{H}_{5}$ fragment that appears in the $233-364^{\circ} \mathrm{C}$ range with DTG maximum at $329^{\circ} \mathrm{C}$. DTA confirms this step by appearing of a sharp exothermic change in the $221-345^{\circ} \mathrm{C}$ range with maximum at $271^{\circ} \mathrm{C}$ indicating decomposition of the ligand. Final decomposition of the ligand takes place in the $435-597^{\circ} \mathrm{C}$ range with DTG maximum at $490^{\circ} \mathrm{C}$ and weight loss of $42.85 \%$ (calcd. 43.0\%). This step is confirmed by two successive exothermic changes in the $435-505^{\circ} \mathrm{C}$ and $506-595^{\circ} \mathrm{C}$ range with DTA maxima at 465 and $543^{\circ} \mathrm{C}$.
The ligand has no plateau at $700{ }^{\circ} \mathrm{C}$ which indicates that it is not completely decomposed.

Copper(II) complexes decompose in four steps for $\left[\mathrm{Cu}\left(\mathrm{HL}_{2}{ }_{2}\right.\right.$ ) $3 .\left(\mathrm{NO}_{3}\right)_{2} \cdot 5 \mathrm{H}_{2} \mathrm{O}$ and $\left[\mathrm{Cu}\left(\mathrm{HL}_{2}^{2}\right)\right] \cdot\left(\mathrm{NO}_{3}\right)_{2} \cdot 1 \frac{1}{2} \mathrm{H}_{2} \mathrm{O}$ and three steps for $[\mathrm{Cu}(\mathrm{HL}$ 2 )]. $\left(\mathrm{NQ}_{3}\right)_{2}$. The dehydration process takes place in the first two steps for $\left[\mathrm{Cu}\left(\mathrm{HL}_{2}\right)\right] \cdot\left(\mathrm{NO}_{3}\right)_{2} \cdot 5 \mathrm{H}_{2} \mathrm{O}$ complex in the $25-90$ and $145-187^{\circ} \mathrm{C}$ range with TGA maxima at 55 and $166^{\circ} \mathrm{C}$. This process is associated with mass loss of 3.9 and $5.86 \%$ (calcd. 3.9 and 5.5\%) representing the elimination of two and three molecules of crystallization water accompanied with DTA change in the 32-92 and $150-187^{\circ} \mathrm{C}$ range with endothermic and exothermic peaks at $62^{\circ} \mathrm{C}$ and $163^{\circ} \mathrm{C}$. This indicates that the complex has two different types of hydrated water, loosely and strongly bound water. The dehydration process of $\left[\mathrm{Cu}\left(\mathrm{HL}_{2}\right)\right] \cdot\left(\mathrm{NO}_{3}\right)_{2} \cdot 1 \frac{1}{2} \mathrm{H}_{2} \mathrm{O}$ complex takes place in the first step in the $30-72^{\circ} \mathrm{C}$ 
range with DTG maximum at $56^{\circ} \mathrm{C}$ with mass loss of $2.97 \%$ (calcd. $2.94 \%$ ) indicating dehydration of $1 \frac{1}{2}$ molecule of hydrated water. DTA confirms this step by endothermic change in the $32-72^{\circ} \mathrm{C}$ range with maximum at $53^{\circ} \mathrm{C}$. Evaporation of the nitrate ions and partial decomposition of the ligand start in the third step for the $\left[\mathrm{Cu}\left(\mathrm{HL}_{2}\right)\right] .\left(\mathrm{NO}_{3}\right)_{2} \cdot 5 \mathrm{H}_{2} \mathrm{O}$ in the $190-270^{\circ} \mathrm{C}$ range with DTG maximum at $245^{\circ} \mathrm{C}$ associated with mass loss of $20.0 \%$ (calcd. $20.17 \%$ ). This step is confirmed by appearance of exothermic change in the $202-282^{\circ} \mathrm{C}$ range with DTA maximum at $247^{\circ} \mathrm{C}$. This process takes place in the second step for $\left[\mathrm{Cu}\left(\mathrm{HL}_{2}^{2}\right)\right] \cdot\left(\mathrm{NO}_{3}\right)_{2} \cdot 1 \frac{1}{2} \mathrm{H}_{2} \mathrm{O}$ in the $170-207^{\circ} \mathrm{C}$ range with $\mathrm{DTG}$ maximum at $194^{\circ} \mathrm{C}$ and mass loss of $15.6 \%$ (calcd. $15.5 \%$ ). DTA confirms this step by sharp exothermic change in the $178-220^{\circ} \mathrm{C}$ with maximum at $196^{\circ} \mathrm{C}$ related to the melting process of the complex. $\left[\mathrm{Cu}\left(\mathrm{HL}_{2}\right)\right]$. $\left(\mathrm{NO}_{3}\right)_{2}$ loses its nitrate ions as nitric acid in the first step in the $240-275^{\circ} \mathrm{C}$ range with DTG maximum at $260^{\circ} \mathrm{C}$ accompanied with mass loss of $14.0 \%$ (calcd. $14.03 \%$ ). This step is shown by exothermic DTA change in the $252-275^{\circ} \mathrm{C}$ range with maximum at $259^{\circ} \mathrm{C}$. The ligand continues decomposition in $\left[\mathrm{Cu}\left(\mathrm{HL}_{2}\right)\right] \cdot\left(\mathrm{NO}_{3}\right)_{2} \cdot 5 \mathrm{H}_{2} \mathrm{O}$ where $33 \%$ of the ligand decomposes in the $280-342^{\circ} \mathrm{C}$ range with DTG maximum at $305^{\circ} \mathrm{C}$ and mass loss of $23.0 \%$ (calcd. $23.13 \%$ ). This complex has no plateau at $700 \mathrm{C}$ indicating incomplete decomposition. In the $\left[\mathrm{Cu}\left(\mathrm{HL}_{2}^{2}\right)\right] .\left(\mathrm{NO}_{3}\right)_{2} \cdot 1 \frac{1}{2} \mathrm{H}_{2} \mathrm{O}$ complex $44 \%$ of the ligand decomposes in the $207-347^{\circ} \mathrm{C}$ range with two DTG maxima at $260^{\circ} \mathrm{C}$ and $311^{\circ} \mathrm{C}$ accompanied with mass loss of $33.37 \%$ (calcd. 33.69\%) and endothermic DTA change in the $262-340^{\circ} \mathrm{C}$ range with maximum at $302^{\circ} \mathrm{C}$. The complex reaches final decomposition with formation of $\mathrm{CuO}$ in the $430-582^{\circ} \mathrm{C}$ range with DTG maximum at $487^{\circ} \mathrm{C}$ and mass loss of $39.56 \%$ (calcd. $39.82 \%$ ). DT A confirms this step by exothermic change at $481^{\circ} \mathrm{C}$. The ligand in $\left[\mathrm{Cu}\left(\mathrm{HL}_{2}\right)\right] .\left(\mathrm{NO}_{3}\right)_{2}$ decomposes in the $320-390^{\circ} \mathrm{C}$ and $510-570^{\circ} \mathrm{C}$ range with DTG maxima at $303,346,373$ and $537^{\circ} \mathrm{C}$, and mass loss of 58.52 and $6.4 \%$ (calcd. 58.59 and $5.91 \%$ ), respectively. DTA confirms this decomposition by exothermic changes in the $280-511$ and $512-578^{\circ} \mathrm{C}$ range with maxima at $308,349,380$ and $548^{\circ} \mathrm{C}$, respectively. The complex has no plateau at $700{ }^{\circ} \mathrm{C}$ indicating incomplete decomposition.

Table 3: TGA. and DTG data of the $\mathrm{HL}^{1}, \mathrm{HL}^{2}$ and $\mathrm{HL}^{3}$ Schiff-bases and their complexes.

\begin{tabular}{|c|c|c|c|c|c|c|c|}
\hline \multirow{2}{*}{ Compound } & \multirow{2}{*}{$\begin{array}{l}\text { Temp. } \\
\text { range }{ }^{\circ} \mathrm{C}\end{array}$} & \multirow{2}{*}{$\begin{array}{l}\text { DTG } \\
{ }^{\circ} \mathrm{C}\end{array}$} & \multicolumn{2}{|c|}{ Mass loss $\%$} & \multirow{2}{*}{ Process } & \multirow{2}{*}{ Product } & \multirow{2}{*}{$\begin{array}{c}\begin{array}{c}\text { Residue } \% \\
\text { and type }\end{array} \\
\text { Found(Calcd.) }\end{array}$} \\
\hline & & & Found & Calcd. & & & \\
\hline $\mathrm{HL}^{1}$ & $\begin{array}{c}95-140 \\
233-364 \\
435-597\end{array}$ & $\begin{array}{l}124 \\
329 \\
490\end{array}$ & $\begin{array}{c}5.25 \\
50.0 \\
42.85\end{array}$ & $\begin{array}{c}4.98 \\
50.18 \\
43.0\end{array}$ & $\begin{array}{l}\text { Partial decomposition } \\
\text { Decomposition } \\
\text { Final decomposition }\end{array}$ & $\begin{array}{c}\mathrm{NH}_{3} \\
\mathrm{CH}_{2} \mathrm{CONHNCHC}_{6} \mathrm{H}_{5} \\
0.43 \mathrm{~L}\end{array}$ & Not complete \\
\hline$\left[\mathrm{Cu}\left(\mathrm{H} \mathrm{L}_{2}^{1}\right)\right] \cdot\left(\mathrm{NO}_{3}\right)_{2} .5 \mathrm{H}_{2} \mathrm{O}$ & $\begin{array}{c}25-90 \\
145-187 \\
190-270 \\
280-342\end{array}$ & $\begin{array}{l}55 \\
166 \\
245 \\
305\end{array}$ & $\begin{array}{c}3.9 \\
5.86 \\
20.0 \\
23.0\end{array}$ & $\begin{array}{c}3.9 \\
5.5 \\
20.17 \\
23.13\end{array}$ & $\begin{array}{c}\text { Dehydration } \\
\text { Dehydration } \\
\text { Partial decomposition } \\
\text { Decomposition }\end{array}$ & $\begin{array}{c}2 \mathrm{H}_{2} \mathrm{O} \\
3 \mathrm{H}_{2} \mathrm{O} \\
2 \mathrm{HNO}_{3}+0.09 \mathrm{~L} \\
0.33 \mathrm{~L}\end{array}$ & Not complete \\
\hline$\left[\mathrm{Fe}_{2} \mathrm{~L}^{1}\left(\mathrm{NO}_{3}\right)_{5}\left(\mathrm{H}_{2} \mathrm{O}\right)_{2}\right] \cdot 4 \mathrm{H}_{2} \mathrm{O}$ & $\begin{array}{r}19-124 \\
182-245 \\
312-488\end{array}$ & $\begin{array}{c}59 \\
107 \\
219 \\
374 \\
427\end{array}$ & $\begin{array}{l}15.06 \\
31.44\end{array}$ & $\begin{array}{l}8.47 \\
14.82 \\
31.39\end{array}$ & $\begin{array}{l}\text { Dehydration } \\
\text { Coordination sphere } \\
\text { Coordination sphere }\end{array}$ & $\begin{array}{c}4 \mathrm{H}_{2} \mathrm{O} \\
2 \mathrm{HNO}_{3} \\
3 \mathrm{HNO}_{3}+2 \mathrm{H}_{2} \mathrm{O}+0.13 \mathrm{~L}\end{array}$ & Not complete \\
\hline$\left[\mathrm{Zn}_{2} \mathrm{~L}^{1}\left(\mathrm{H}_{2} \mathrm{O}\right)_{4}\right] \cdot\left(\mathrm{NO}_{3}\right)_{3} \cdot \mathrm{H}_{2} \mathrm{O}$ & $\begin{array}{c}20-130 \\
194-335 \\
345-447\end{array}$ & $\begin{array}{c}93 \\
254 \\
407\end{array}$ & $\begin{array}{l}2.88 \\
9.60 \\
8.26\end{array}$ & $\begin{array}{l}2.48 \\
9.91 \\
8.52\end{array}$ & $\begin{array}{l}\text { Dehydration } \\
\text { Coordinated water } \\
\text { Ionization sphere }\end{array}$ & $\begin{array}{l}\mathrm{H}_{2} \mathrm{O} \\
4 \mathrm{H}_{2} \mathrm{O} \\
\mathrm{HNO}_{3}\end{array}$ & Not complete \\
\hline$\left[\mathrm{Mn}_{2} \mathrm{~L}^{1}\left(\mathrm{H}_{2} \mathrm{O}\right)_{4}\right] \cdot\left(\mathrm{NO}_{3}\right)_{3} \cdot . \mathrm{H}_{2} \mathrm{O}$ & $\begin{array}{c}30-132 \\
133-192 \\
252-392\end{array}$ & $\begin{array}{c}53 \\
154 \\
296\end{array}$ & $\begin{array}{c}2.8 \\
4.88 \\
4.73\end{array}$ & $\begin{array}{l}2.55 \\
5.10 \\
5.10\end{array}$ & $\begin{array}{c}\text { Dehydration } \\
\text { Coordinated water } \\
\text { Coordinated water }\end{array}$ & $\begin{array}{l}\mathrm{H}_{2} \mathrm{O} \\
2 \mathrm{H}_{2} \mathrm{O} \\
2 \mathrm{H}_{2} \mathrm{O}\end{array}$ & Not complete \\
\hline$\left[\mathrm{Cu}\left(\mathrm{HL}_{2}\right)\right] \cdot\left(\mathrm{NO}_{3}\right)_{2} \cdot 1 \frac{1}{2} \mathrm{H}_{2} \mathrm{O}$ & $\begin{array}{c}26-62 \\
170-207 \\
207-347 \\
430-582\end{array}$ & $\begin{array}{c}46 \\
194 \\
260 \\
311 \\
487\end{array}$ & $\begin{array}{c}2.97 \\
15.60 \\
33.37 \\
\\
39.56\end{array}$ & $\begin{array}{c}2.94 \\
15.38 \\
33.69 \\
\\
39.82\end{array}$ & $\begin{array}{c}\text { Dehydration } \\
\text { Ionization sphere } \\
\text { Partial decomposition } \\
\text { Final Decomposition }\end{array}$ & $\begin{array}{c}1.5 \mathrm{H}_{2} \mathrm{O} \\
2 \mathrm{HNO}_{3}+\mathrm{CH}_{3} \\
0.44 \mathrm{~L} \\
0.52 \mathrm{~L}\end{array}$ & $\begin{array}{c}8.52(8.68) \\
\mathrm{CuO}\end{array}$ \\
\hline$\left[\mathrm{Fe}_{2} \mathrm{~L}^{2}\left(\mathrm{NO}_{3}\right)_{5}\left(\mathrm{H}_{2} \mathrm{O}\right)_{2}\right] \cdot \mathrm{H}_{2} \mathrm{O}$ & $\begin{array}{c}22-63 \\
205-302 \\
\\
330-367 \\
418-455 \\
456-563\end{array}$ & $\begin{array}{c}47 \\
238 \\
267 \\
358 \\
443 \\
522\end{array}$ & $\begin{array}{c}15.5 \\
5.5 \\
28.11\end{array}$ & $\begin{array}{c}15.25 \\
5.52 \\
28.49\end{array}$ & $\begin{array}{l}\text { Dehydration } \\
\text { Coordination sphere } \\
\\
\text { Coordination sphere } \\
\text { Partial decomposition } \\
\text { Final decomposition }\end{array}$ & $\begin{array}{c}\mathrm{H}_{2} \mathrm{O} \\
3 \mathrm{HNO}_{3}+2 \mathrm{H}_{2} \mathrm{O} \\
2 \mathrm{HNO}_{3} \\
0.13 \mathrm{~L} \\
0.67 \mathrm{~L}\end{array}$ & $\begin{array}{c}\mathrm{Fe}_{3} \mathrm{O}_{4} \\
21.0(18.7)\end{array}$ \\
\hline
\end{tabular}




\begin{tabular}{|c|c|c|c|c|c|c|c|}
\hline \multicolumn{8}{|c|}{ Table (3): Continued } \\
\hline $\begin{array}{l}{\left[\mathrm{Zn}_{2} \mathrm{~L}^{2}\left(\mathrm{H}_{2} \mathrm{O}\right)_{4}\right]} \\
\left(\mathrm{NO}_{3}\right)_{3} \cdot 1 / 2 \mathrm{H}_{2} \mathrm{O}\end{array}$ & $\begin{array}{c}19-80 \\
219-315 \\
355-448\end{array}$ & $\begin{array}{c}56 \\
287 \\
386\end{array}$ & $\begin{array}{c}1.34 \\
9.51 \\
11.76\end{array}$ & $\begin{array}{c}1.20 \\
9.63 \\
11.71\end{array}$ & $\begin{array}{c}\text { Dehydration } \\
\text { Coordinated water } \\
\text { Partial decomposition }\end{array}$ & $\begin{array}{c}0.5 \mathrm{H}_{2} \mathrm{O} \\
4 \mathrm{H}_{2} \mathrm{O} \\
\mathrm{HNO}_{3}+0.07 \mathrm{~L}\end{array}$ & Not complete \\
\hline $\begin{array}{l}{\left[\mathrm{Mn}_{2} \mathrm{~L}^{2}\left(\mathrm{H}_{2} \mathrm{O}\right)_{4}\right]} \\
\left(\mathrm{NO}_{3}\right)_{3} \cdot 1 \frac{1}{2} \mathrm{H}_{2} \mathrm{O}\end{array}$ & $\begin{array}{c}26-100 \\
105-200 \\
201-437\end{array}$ & $\begin{array}{c}67 \\
31 \\
187 \\
294 \\
332 \\
\end{array}$ & $\begin{array}{l}3.96 \\
9.42 \\
\\
34.97\end{array}$ & $\begin{array}{l}3.62 \\
9.66 \\
35.26\end{array}$ & $\begin{array}{c}\text { Dehydration } \\
\text { Coordinated water } \\
\text { Partial decomposition }\end{array}$ & $\begin{array}{c}1.5 \mathrm{H}_{2} \mathrm{O} \\
4 \mathrm{H}_{2} \mathrm{O} \\
3 \mathrm{HNO}_{3}+0.21 \mathrm{~L}\end{array}$ & Not complete \\
\hline$\left[\mathrm{Cu}\left(\mathrm{HL}_{2}^{3}\right)\right] \cdot\left(\mathrm{NO}_{3}\right)_{2}$ & $\begin{array}{r}240-275 \\
320-390 \\
510-570\end{array}$ & $\begin{array}{l}260 \\
303 \\
346 \\
373 \\
537\end{array}$ & $\begin{array}{r}27.35 \\
58.52 \\
\\
6.4\end{array}$ & $\begin{array}{l}27.57 \\
58.59 \\
\\
5.91\end{array}$ & $\begin{array}{l}\text { Ionization sphere } \\
\text { Decomposition } \\
\text { Ligand decomposition }\end{array}$ & $\begin{array}{c}2 \mathrm{HNO}_{3} \\
0.74 \mathrm{~L} \\
0.07 \mathrm{~L}\end{array}$ & Not complete \\
\hline $\begin{array}{c}{\left[\mathrm{Fe}_{2} \mathrm{~L}^{3}\left(\mathrm{NO}_{3}\right)_{3}\left(\mathrm{H}_{2} \mathrm{O}\right)_{2}\right] \cdot\left(\mathrm{NO}_{3}\right)} \\
{ }_{2} \cdot 2 \mathrm{H}_{2} \mathrm{O}\end{array}$ & $\begin{array}{c}28-110 \\
182-298 \\
312-400\end{array}$ & $\begin{array}{c}63 \\
230 \\
350 \\
379\end{array}$ & $\begin{array}{c}3.90 \\
14.67 \\
26.21\end{array}$ & $\begin{array}{c}4.24 \\
14.85 \\
26.52\end{array}$ & $\begin{array}{c}\text { Dehydration } \\
\text { Ionization sphere } \\
\text { Coordination sphere }\end{array}$ & $\begin{array}{c}2 \mathrm{H}_{2} \mathrm{O} \\
2 \mathrm{HNO}_{3} \\
3 \mathrm{HNO}_{3}+2 \mathrm{H}_{2} \mathrm{O}\end{array}$ & Not complete \\
\hline$\left[\mathrm{Zn}_{2} \mathrm{~L}^{3}\left(\mathrm{H}_{2} \mathrm{O}\right)_{4}\right] \cdot\left(\mathrm{NO}_{3}\right)_{3} \cdot \mathrm{H}_{2} \mathrm{O}$ & $\begin{array}{l}158-231 \\
232-395 \\
\\
406-453 \\
477-657\end{array}$ & $\begin{array}{l}213 \\
299 \\
\\
436 \\
564\end{array}$ & $\begin{array}{c}2.75 \\
25.87 \\
\\
8.0 \\
37.12\end{array}$ & $\begin{array}{c}3.33 \\
26.01 \\
\\
8.27 \\
37.35\end{array}$ & $\begin{array}{l}\text { Dehydration } \\
\text { Ionization sphere }+ \\
\text { coordinated water } \\
\text { Ionization sphere. } \\
\text { Final decomposition }\end{array}$ & $\begin{array}{c}\mathrm{H}_{2} \mathrm{O} \\
4 \mathrm{H}_{2} \mathrm{O}+2 \mathrm{HNO}_{3} \\
\mathrm{HNO}_{3} \\
0.8 \mathrm{~L}\end{array}$ & $\begin{array}{c}25.71 / 21.39 \\
\mathrm{ZnO}\end{array}$ \\
\hline $\begin{array}{l}{\left[\mathrm{Mn}_{2} \mathrm{~L}^{3}\left(\mathrm{H}_{2} \mathrm{O}\right)_{4}\right]} \\
\left(\mathrm{NO}_{3}\right)_{3} \cdot 3 \mathrm{H}_{2} \mathrm{O}\end{array}$ & $\begin{array}{c}13-93 \\
237-320 \\
377-547\end{array}$ & $\begin{array}{c}53 \\
288 \\
409\end{array}$ & $\begin{array}{c}7.35 \\
19.68 \\
16.95\end{array}$ & $\begin{array}{c}6.95 \\
19.43 \\
17.39\end{array}$ & $\begin{array}{c}\text { Dehydration } \\
\text { Partial decomposition } \\
\text { Ionization sphere }+ \\
\text { coordinated water }\end{array}$ & $\begin{array}{c}3 \mathrm{H}_{2} \mathrm{O} \\
2 \mathrm{HNO}_{3}+0.07 \mathrm{~L} \\
\mathrm{HNO}_{3}+4 \mathrm{H}_{2} \mathrm{O}\end{array}$ & Not complete \\
\hline
\end{tabular}

Table 4: DTA data of the $\mathrm{HL}^{1}, \mathrm{HL}^{2}$ and $\mathrm{HL}^{3}$ Schiff-bases and their complexes.

\begin{tabular}{|c|c|c|c|c|}
\hline Compounds & $\begin{array}{l}\text { Temp. } \\
\text { rang. }{ }^{\circ} \mathrm{C}\end{array}$ & DTA peak ${ }^{\circ} \mathrm{C}$ & $\Delta \mathrm{H} \mathrm{J} / \mathrm{g}$ & Process \\
\hline $\mathrm{HL}^{1}$ & $\begin{array}{l}100-140 \\
195-220 \\
221-345 \\
435-505 \\
506-595\end{array}$ & $\begin{array}{ll}124 & \text { endo. } \\
203 & \text { endo. } \\
271 & \text { exo. } \\
465 & \text { exo. } \\
543 & \text { exo. }\end{array}$ & $\begin{array}{c}314 \\
429 \\
-300 \\
-461 \\
-1120\end{array}$ & $\begin{array}{c}\text { Partial decomposition } \\
\text { Melting } \\
\text { Decomposition } \\
\text { Decomposition } \\
\text { Final decomposition }\end{array}$ \\
\hline$\left[\mathrm{Cu}\left(\mathrm{HL}_{2}^{1}\right)\right] \cdot\left(\mathrm{NO}_{3}\right)_{2} \cdot 5 \mathrm{H}_{2} \mathrm{O}$ & $\begin{array}{c}32-92 \\
150-187 \\
202-282\end{array}$ & $\begin{array}{ll}62 & \text { endo. } \\
163 & \text { exo. } \\
247 & \text { exo. }\end{array}$ & $\begin{array}{l}132 \\
-19 \\
-337\end{array}$ & $\begin{array}{l}\text { Dehydration } \\
\text { Dehydration } \\
\text { Ionization sphere }\end{array}$ \\
\hline$\left[\mathrm{Fe}_{2} \mathrm{~L}^{1}\left(\mathrm{NO}_{3}\right)_{5}\left(\mathrm{H}_{2} \mathrm{O}\right)_{2}\right] \cdot 4 \mathrm{H}_{2} \mathrm{O}$ & $\begin{array}{l}30-124 \\
184-206 \\
279-494\end{array}$ & $\begin{array}{l}64 \text { endo. } \\
109 \\
219 \text { endo. } \\
379 \text { exo. } \\
427 \text { exo. }\end{array}$ & $\begin{array}{c}70 \\
36 \\
58 \\
-6430\end{array}$ & $\begin{array}{c}\text { Dehydration } \\
\text { Coordination sphere } \\
\text { Coordination sphere }\end{array}$ \\
\hline$\left[\mathrm{Zn}_{2} \mathrm{~L}^{1}\left(\mathrm{H}_{2} \mathrm{O}\right)_{4}\right] \cdot\left(\mathrm{NO}_{3}\right)_{3} \cdot \mathrm{H}_{2} \mathrm{O}$ & $\begin{array}{l}120-140 \\
313-329 \\
357-442\end{array}$ & $\begin{array}{c}132 \text { endo. } \\
317 \text { endo. } \\
404 \text { exo. }\end{array}$ & $\begin{array}{c}30 \\
34 \\
238\end{array}$ & $\begin{array}{c}\text { Dehydration } \\
\text { Coordinated water } \\
\text { Ionization sphere }\end{array}$ \\
\hline$\left[\mathrm{Mn}_{2} \mathrm{~L}^{1}\left(\mathrm{H}_{2} \mathrm{O}\right)_{4}\right] \cdot\left(\mathrm{NO}_{3}\right)_{3} \cdot \mathrm{H}_{2} \mathrm{O}$ & $\begin{array}{c}30-85 \\
128-150 \\
277-330\end{array}$ & $\begin{array}{ll}62 & \text { endo. } \\
132 & \text { endo. } \\
303 & \text { exo. }\end{array}$ & $\begin{array}{r}22 \\
31 \\
-69\end{array}$ & $\begin{array}{c}\text { Dehydration } \\
\text { Coordinated water } \\
\text { Coordinated water }\end{array}$ \\
\hline$\left[\mathrm{Cu}\left(\mathrm{H} \mathrm{L}_{2}^{2}\right)\right] \cdot\left(\mathrm{NO}_{3}\right)_{2} \cdot 1 \frac{1}{2} \mathrm{H}_{2} \mathrm{O}$ & $\begin{array}{c}32-72 \\
178-220 \\
262-340 \\
415-598\end{array}$ & $\begin{array}{cc}51 & \text { endo. } \\
196 & \text { exo. } \\
302 & \text { endo. } \\
481 & \text { exo. }\end{array}$ & $\begin{array}{c}91 \\
-174 \\
142 \\
-7950\end{array}$ & $\begin{array}{c}\text { Dehydration } \\
\text { Melting } \\
\text { Partial decomposition } \\
\text { Final decomposition }\end{array}$ \\
\hline
\end{tabular}


Table 4. Continued

\begin{tabular}{|c|c|c|c|c|}
\hline$\left[\mathrm{Fe}_{2} \mathrm{~L}^{2}\left(\mathrm{NO}_{3}\right)_{5}\left(\mathrm{H}_{2} \mathrm{O}\right)_{2}\right] \cdot \mathrm{H}_{2} \mathrm{O}$ & $\begin{array}{c}32-82 \\
206-221 \\
221-261 \\
300-405 \\
406-455 \\
456-580 \\
\end{array}$ & $\begin{array}{ll}58 & \text { endo. } \\
220 & \text { endo. } \\
236 & \text { exo. } \\
363 & \text { exo. } \\
443 & \text { exo. } \\
535 & \text { exo. }\end{array}$ & $\begin{array}{c}25 \\
174 \\
-272 \\
-651 \\
-240 \\
-5150 \\
\end{array}$ & $\begin{array}{c}\text { Dehydration } \\
\text { Melting } \\
\text { Coordination sphere } \\
\text { Coordination sphere } \\
\text { Partial decomposition } \\
\text { Final decomposition }\end{array}$ \\
\hline$\left[\mathrm{Zn}_{2} \mathrm{~L}^{2}\left(\mathrm{H}_{2} \mathrm{O}\right)_{4}\right] \cdot\left(\mathrm{NO}_{3}\right)_{3} \cdot 1 / 2 \mathrm{H}_{2} \mathrm{O}$ & $\begin{array}{c}64-132 \\
298-315 \\
316-427\end{array}$ & $\begin{array}{ll}97 & \text { endo. } \\
303 & \text { endo. } \\
391 & \text { exo. }\end{array}$ & $\begin{array}{c}10 \\
62 \\
-1100\end{array}$ & $\begin{array}{c}\text { Dehydration } \\
\text { Melting } \\
\text { Partial decomposition }\end{array}$ \\
\hline$\left[\mathrm{Mn}_{2} \mathrm{~L}^{2}\left(\mathrm{H}_{2} \mathrm{O}\right)_{4}\right] \cdot\left(\mathrm{NO}_{3}\right)_{3} \cdot 1 \frac{1}{2} \mathrm{H}_{2} \mathrm{O}$ & $\begin{array}{c}26-61 \\
118-150 \\
151-239 \\
240-335\end{array}$ & $\begin{array}{cc}43 & \text { endo. } \\
137 & \text { endo. } \\
203 & \text { endo. } \\
299 & \text { exo }\end{array}$ & $\begin{array}{r}34 \\
59 \\
141 \\
-399 \\
\end{array}$ & $\begin{array}{c}\text { Dehydration } \\
\text { Coordinated water } \\
\text { Partial decomposition } \\
\text { Partial decomposition }\end{array}$ \\
\hline$\left[\mathrm{Cu}\left(\mathrm{H} \mathrm{L}_{2}^{3}\right)\right] \cdot\left(\mathrm{NO}_{3}\right)_{2}$ & $\begin{array}{l}252-275 \\
280-511 \\
512-578\end{array}$ & $\begin{array}{l}259 \text { exo. } \\
308 \\
349 \text { exo. } \\
380 \\
548 \quad \text { exo. }\end{array}$ & $\begin{array}{l}-308 \\
-1071 \\
-289\end{array}$ & $\begin{array}{l}\text { Partial decomposition } \\
\text { Ligand decomposition } \\
\text { Final decomposition }\end{array}$ \\
\hline$\left[\mathrm{Fe}_{2} \mathrm{~L}^{3}\left(\mathrm{NO}_{3}\right)_{3}\left(\mathrm{H}_{2} \mathrm{O}\right)_{2}\right] \cdot\left(\mathrm{NO}_{3}\right)_{2} \cdot 2 \mathrm{H}_{2} \mathrm{O}$ & $\begin{array}{c}33-88 \\
298-309 \\
310-448\end{array}$ & $\begin{array}{ll}66 & \text { endo. } \\
303 & \text { endo. } \\
352 & \text { exo. } \\
& 382\end{array}$ & $\begin{array}{c}106 \\
205 \\
-2190\end{array}$ & $\begin{array}{l}\text { Dehydration } \\
\text { Melting } \\
\text { Coordination sphere }\end{array}$ \\
\hline$\left[\mathrm{Zn}_{2} \mathrm{~L}^{3}\left(\mathrm{H}_{2} \mathrm{O}\right)_{4}\right] \cdot\left(\mathrm{NO}_{3}\right)_{3} \cdot \mathrm{H}_{2} \mathrm{O}$ & $\begin{array}{l}166-227 \\
350-388 \\
\\
427-453 \\
474-657\end{array}$ & $\begin{array}{ll}210 & \text { endo. } \\
367 & \text { endo. } \\
& \\
443 & \text { exo. } \\
569 & \text { exo. }\end{array}$ & $\begin{array}{c}190 \\
61 \\
\\
-31 \\
-5600\end{array}$ & $\begin{array}{l}\text { Dehydration } \\
\text { Ionization sphere+ } \\
\text { coordinated water } \\
\text { Ionization sphere. } \\
\text { Final decomposition }\end{array}$ \\
\hline$\left[\mathrm{Mn}_{2} \mathrm{~L}^{3}\left(\mathrm{H}_{2} \mathrm{O}\right)_{4}\right] \cdot\left(\mathrm{NO}_{3}\right)_{3} \cdot 3 \mathrm{H}_{2} \mathrm{O}$ & $\begin{array}{c}27-100 \\
222-322\end{array}$ & $\begin{array}{l}60 \text { endo. } \\
290 \text { exo. }\end{array}$ & $\begin{array}{c}782 \\
-2870\end{array}$ & $\begin{array}{c}\text { Dehydration } \\
\text { Partial decomposition }\end{array}$ \\
\hline
\end{tabular}

Thermal decomposition of the iron(III) complexes takes place in three steps for $\left[\mathrm{Fe}_{2} \mathrm{~L}^{1}\left(\mathrm{NO}_{3}\right)_{5}\left(\mathrm{H}_{2} \mathrm{O}\right)_{2}\right] \cdot 4 \mathrm{H}_{2} \mathrm{O}$ and $\left[\mathrm{Fe}_{2} \mathrm{~L}^{3}\left(\mathrm{NO}_{3}\right)_{3}\left(\mathrm{H}_{2} \mathrm{O}\right)_{2}\right] .\left(\mathrm{NO}_{3}\right)_{2} \cdot 2 \mathrm{H}_{2} \mathrm{O}$ and five steps for $\left[\mathrm{Fe}_{2} \mathrm{~L}^{2}\left(\mathrm{NO}_{3}\right)_{5}\left(\mathrm{H}_{2} \mathrm{O}\right)_{2}\right] \cdot \mathrm{H}_{2} \mathrm{O}$. Dehydration process takes place in the first stage in the $30-124,30-63$ and $28-110^{\circ} \mathrm{C}$ range with DTG maxima at 59, 107; 52 and $63^{\circ} \mathrm{C}$ for $\left[\mathrm{Fe}_{2} \mathrm{~L}^{1}\left(\mathrm{NO}_{3}\right)_{5}\left(\mathrm{H}_{2} \mathrm{O}\right)_{2}\right] \cdot 4 \mathrm{H}_{2} \mathrm{O},\left[\mathrm{Fe}_{2} \mathrm{~L}^{2}\left(\mathrm{NO}_{3}\right)_{5}\left(\mathrm{H}_{2} \mathrm{O}\right)_{2}\right]$. $\mathrm{H}_{2} \mathrm{O}$ and $\left[\mathrm{Fe}_{2} \mathrm{~L}^{3}\left(\mathrm{NO}_{3}\right)_{3}\left(\mathrm{H}_{2} \mathrm{O}\right)_{2}\right] .\left(\mathrm{NO}_{3}\right)_{2} .2 \mathrm{H}_{2} \mathrm{O}$. This step is correlated with mass loss of $8.28,2.21$ and $3.9 \%$ (calcd. 8.47, 2.18 and $4.24 \%$ ) indicating the dehydration of four, one and two water molecules, respectively. DTA confirms this step by endothermic changes at 64,$109 ; 58$ and $66^{\circ} \mathrm{C}$. It is noted that $\left[\mathrm{Fe}_{2} \mathrm{~L}^{1}\left(\mathrm{NO}_{3}\right)_{5}\left(\mathrm{H}_{2} \mathrm{O}\right)_{2}\right] \cdot 4 \mathrm{H}_{2} \mathrm{O}$ dehydrate in two steps which indicates the presence of two types of crystallization water. $\left[\mathrm{Fe}_{2} \mathrm{~L}^{1}\left(\mathrm{NO}_{3}\right)_{5}\left(\mathrm{H}_{2} \mathrm{O}\right)_{2}\right] \cdot 4 \mathrm{H}_{2} \mathrm{O}$ and $\left[\mathrm{Fe}_{2} \mathrm{~L}^{3}\left(\mathrm{NO}_{3}\right)_{3}\left(\mathrm{H}_{2} \mathrm{O}\right)_{2}\right] \cdot\left(\mathrm{NO}_{3}\right)_{2} \cdot 2 \mathrm{H}_{2} \mathrm{O}$ complexes show elimination of two coordinated nitrate ions as nitric acid in the $182-245$ and $182-198^{\circ} \mathrm{C}$ range with DTG maximum at 219 and $230^{\circ} \mathrm{C}$ and mass loss of 15.06 and $14.67 \%$ (calcd. 14.82 and $14.85 \%$ ). In the next step, elimination of three coordinated nitrate ions, two molecules of coordinated water and partial decomposition of the ligand take place in the $312-488$ and $312-400^{\circ} \mathrm{C}$ range with DTG maxima at $374,427^{\circ} \mathrm{C}$ and $350,379^{\circ} \mathrm{C}$ associated with mass loss of 31.44 and $26.21 \%$ (calcd. 31.39 and $26.52 \%$ ). This step is confirmed by a broad exothermic change in the $279-494$ and $310-448^{\circ} \mathrm{C}$ range with maxima at 379,427 and $352,382^{\circ} \mathrm{C}$ for the two complexes. Sharp endothermic peak in the $298-309^{\circ} \mathrm{C}$ range with maximum at $303^{\circ} \mathrm{C}$ is related to the melting process for $\left[\mathrm{Fe}_{2} \mathrm{~L}^{3}\left(\mathrm{NO}_{3}\right)_{3}\left(\mathrm{H}_{2} \mathrm{O}\right)_{2}\right]$. $\left(\mathrm{NO}_{3}\right)_{2} \cdot 2 \mathrm{H}_{2} \mathrm{O}$. Both complexes have no plateau at $700 \mathrm{C}^{\circ}$ which indicates incomplete decomposition. In the complex $\left[\mathrm{Fe}_{2} \mathrm{~L}^{2}\left(\mathrm{NO}_{3}\right)_{5}\left(\mathrm{H}_{2} \mathrm{O}\right)_{2}\right] \cdot \mathrm{H}_{2} \mathrm{O}$, three coordinated nitrate ions and coordinated water are eliminated in the second step while two nitrate ions are lost in the third step which is contrary to the other $\mathrm{Fe}(\mathrm{III})$ complexes. This happens in the $205-302$ and $330-367^{\circ} \mathrm{C}$ range with DTG maxima at 238,267 and $358^{\circ} \mathrm{C}$ correlated with mass loss of 27.15 and $15.5 \%$ (calcd. 27.25 and $15.25 \%$ ). Sharp endothermic peak at $220^{\circ} \mathrm{C}$ indicates melting of the complex followed by decomposition at 236 and $363^{\circ} \mathrm{C}$ in the $221-261$ and $300-405^{\circ} \mathrm{C}$ range. Partial decomposition of the ligand starts in the fourth step in the $418-455^{\circ} \mathrm{C}$ range with DTG maximum at $443^{\circ} \mathrm{C}$ associated with mass loss of 5.5\% (calcd. 5.52\%) and exothermic DTA change in the 406$455^{\circ} \mathrm{C}$ range with maximum at $443^{\circ} \mathrm{C}$. Final decomposition with the formation of $\mathrm{Fe}_{3} \mathrm{O}_{4}$ takes place in the $456-563^{\circ} \mathrm{C}$ range with DTG maximum at $522^{\circ} \mathrm{C}$ and mass loss of $28.11 \%$ (calcd. $28.49 \%$ ). DTA confirms this step by a broad exothermic change in the $456-580^{\circ} \mathrm{C}$ range with maximum at $535^{\circ} \mathrm{C}$.

Thermal decomposition of the Zinc(II) complexes takes place in three steps for $\left[\mathrm{Zn}_{2} \mathrm{~L}^{1}\left(\mathrm{H}_{2} \mathrm{O}\right)_{4}\right] \cdot\left(\mathrm{NO}_{3}\right)_{3} \cdot \mathrm{H}_{2} \mathrm{O}$ and $\left[\mathrm{Zn}_{2} \mathrm{~L}^{2}\left(\mathrm{H}_{2} \mathrm{O}\right)_{4}\right] \cdot\left(\mathrm{NO}_{3}\right)_{3} \cdot{ }^{1} / 2 \mathrm{H}_{2} \mathrm{O}$ complexes and four steps for $\left[\mathrm{Zn}_{2} \mathrm{~L}^{3}\left(\mathrm{H}_{2} \mathrm{O}\right)_{4}\right]$. $\left(\mathrm{NO}_{3}\right)_{3} \cdot \mathrm{H}_{2} \mathrm{O}$ complex. The dehydration process takes place in the $30-130,30-80$ and $158-231^{\circ} \mathrm{C}$ range with DTG maxima at 93 , 56 and $213^{\circ} \mathrm{C}$ associated with mass loss of $2.88,1.34$ and 2.75 (calcd. 2.48, 1.20 and $3.33 \%$ ), respectively. This step was also shown by endothermic peaks at $132,97^{\circ} \mathrm{C}$ and $210^{\circ} \mathrm{C}$, respectively. In $\left[\mathrm{Zn}_{2} \mathrm{~L}^{1}\left(\mathrm{H}_{2} \mathrm{O}\right)_{4}\right] .\left(\mathrm{NO}_{3}\right)_{3} \cdot \mathrm{H}_{2} \mathrm{O}$, the second step is correlated with the elimination of four coordinated water molecules in the $194-335^{\circ} \mathrm{C}$ range with DTG maximum at $254^{\circ} \mathrm{C}$ and mass loss of $9.6 \%$ (calcd. 9.91\%) and also accompanied with endothermic DTA peak at $317^{\circ} \mathrm{C}$. Elimination of the nitrate ions as nitric acid starts in the third step in the 345$447^{\circ} \mathrm{C}$ range with DTG maximum at $407^{\circ} \mathrm{C}$ and mass loss of $8.26 \%$ (calcd. $8.52 \%$ ). This step is confirmed by exothermic change in the $357-442^{\circ} \mathrm{C}$ range with DTA maximum at $404^{\circ} \mathrm{C}$. This complex shows high thermal stability as only $26 \%$ of the complex decomposes in the temperature range of $30-700^{\circ} \mathrm{C}$ and so there is no plateau at $700{ }^{\circ} \mathrm{C}$ indicating incomplete decomposition. In the $\left[\mathrm{Zn}_{2} \mathrm{~L}^{2}\left(\mathrm{H}_{2} \mathrm{O}\right)_{4}\right] .\left(\mathrm{NO}_{3}\right)_{3} .1 / 2 \mathrm{H}_{2} \mathrm{O}$ complex, the coordinated water is eliminated also in the second step in the $219-315^{\circ} \mathrm{C}$ range with DTG maximum at $287^{\circ} \mathrm{C}$ accompanied with weight loss of $9.51 \%$ (calcd. 9.63\%). This complex melts as shown by a sharp endothermic change in the $298-315^{\circ} \mathrm{C}$ range with DTA maximum at $303^{\circ} \mathrm{C}$. Exothermic change in the $316-427^{\circ} \mathrm{C}$ range with maximum at $391^{\circ} \mathrm{C}$ indicates partial decomposition of the complex which appeared in the TGA/DTG curve in the $355-448^{\circ} \mathrm{C}$ range with maximum at $386^{\circ} \mathrm{C}$ and mass loss of $11.76 \%$ (calcd. $11.71 \%$ ). The complex has no plateau at $700{ }^{\circ} \mathrm{C}$ which indicate that it is not completely decomposed. In the $\left[\mathrm{Zn}_{2} \mathrm{~L}^{3}\left(\mathrm{H}_{2} \mathrm{O}\right)_{4}\right] .\left(\mathrm{NO}_{3}\right)_{3}$. $\mathrm{H}_{2} \mathrm{O}$ complex, four coordinated water molecules together with two nitrate ions are eliminated in the second step in the $232-395^{\circ} \mathrm{C}$ range with DTG maximum at $299^{\circ} \mathrm{C}$ and mass loss of $25.87 \%$ (calcd. $26.01 \%$ ). DTA confirms this stage by endothermic peak at $367^{\circ} \mathrm{C}$. In the third step a nitrate ion is eliminated as nitric acid in the $406-453^{\circ} \mathrm{C}$ range with maximum at $436^{\circ} \mathrm{C}$ and mass loss of $8.0 \%$ (calcd. $8.27 \%$ ). This process is accompanied with exothermic DTA change in the $427-453^{\circ} \mathrm{C}$ range with maximum at $443^{\circ} \mathrm{C}$. Final decomposition and formation of $\mathrm{ZnO}$ takes place in the last stage in the $477-657^{\circ} \mathrm{C}$ range with maximum at $564^{\circ} \mathrm{C}$ and mass loss of $37.12 \%$ (calcd. $37.35 \%$ ). DTA calorigram shows this stage as exothermic change with maximum at $569^{\circ} \mathrm{C}$. 
Table 5: Antibacterial screening data of the Schiff-bases and their complexes.

\begin{tabular}{|c|c|c|c|c|}
\hline \multirow{3}{*}{ Compound } & \multicolumn{4}{|c|}{ Zone of Inhibition (mm) } \\
\hline & \multirow{2}{*}{$\begin{array}{c}\text { Gram positive } \\
\text { S. } a \text {. }\end{array}$} & \multicolumn{3}{|c|}{ Gram negative } \\
\hline & & K. $p$. & E. c. & P. v. \\
\hline DMF(Control) & - & - & - & - \\
\hline $\mathrm{HL}^{1}$ & - & 8 & 7 & - \\
\hline$\left[\mathrm{Cu}\left(\mathrm{H} \mathrm{L}_{2}^{1}\right)\right] \cdot\left(\mathrm{NO}_{3}\right)_{2} \cdot 5 \mathrm{H}_{2} \mathrm{O}$ & 15 & 7 & 9 & - \\
\hline$\left[\mathrm{Fe}_{2} \mathrm{~L}^{1}\left(\mathrm{NO}_{3}\right)_{5}\left(\mathrm{H}_{2} \mathrm{O}\right)_{2}\right] \cdot 4 \mathrm{H}_{2} \mathrm{O}$ & 8 & 16 & 6 & - \\
\hline$\left[\mathrm{Zn}_{2} \mathrm{~L}^{1}\left(\mathrm{H}_{2} \mathrm{O}\right)_{4}\right] \cdot\left(\mathrm{NO}_{3}\right)_{3} \cdot \mathrm{H}_{2} \mathrm{O}$ & - & - & - & - \\
\hline$\left[\mathrm{Mn}_{2} \mathrm{~L}^{1}\left(\mathrm{H}_{2} \mathrm{O}\right)_{4}\right] \cdot\left(\mathrm{NO}_{3}\right)_{3} \cdot \mathrm{H}_{2} \mathrm{O}$ & 7 & 9 & 6 & - \\
\hline $\mathrm{HL}^{2}$ & 5 & 8 & 7 & - \\
\hline$\left[\mathrm{Cu}\left(\mathrm{H} \mathrm{L}_{2}^{2}\right)\right] \cdot\left(\mathrm{NO}_{3}\right)_{2} \cdot 1 \frac{1}{2} \mathrm{H}_{2} \mathrm{O}$ & 16 & 7 & 9 & - \\
\hline$\left[\mathrm{Fe}_{2} \mathrm{~L}^{2}\left(\mathrm{NO}_{3}\right)_{5}\left(\mathrm{H}_{2} \mathrm{O}\right)_{2}\right] \cdot \mathrm{H}_{2} \mathrm{O}$ & 15 & 6 & 8 & - \\
\hline$\left[\mathrm{Zn}_{2} \mathrm{~L}^{2}\left(\mathrm{H}_{2} \mathrm{O}\right)_{4}\right] \cdot\left(\mathrm{NO}_{3}\right)_{3} \cdot 1 / 2 \mathrm{H}_{2} \mathrm{O}$ & - & - & - & - \\
\hline$\left[\mathrm{Mn}_{2} \mathrm{~L}^{2}\left(\mathrm{H}_{2} \mathrm{O}\right)_{4}\right] \cdot\left(\mathrm{NO}_{3}\right)_{3} \cdot 1 \frac{1}{2} \mathrm{H}_{2} \mathrm{O}$ & 7 & 9 & 5 & - \\
\hline $\mathrm{HL}^{3}$ & 6 & 8 & 7 & - \\
\hline$\left[\mathrm{Cu}\left(\mathrm{H} \mathrm{L}_{2}^{3}\right)\right] \cdot\left(\mathrm{NO}_{3}\right)_{2}$ & 17 & 8 & 6 & - \\
\hline$\left[\mathrm{Fe}_{2} \mathrm{~L}^{3}\left(\mathrm{NO}_{3}\right)_{3}\left(\mathrm{H}_{2} \mathrm{O}\right)_{2}\right] \cdot\left(\mathrm{NO}_{3}\right)_{2} \cdot \mathrm{H}_{2} \mathrm{O}$ & 5 & 7 & 7 & - \\
\hline$\left[\mathrm{Zn}_{2} \mathrm{~L}^{3}\left(\mathrm{H}_{2} \mathrm{O}\right)_{4}\right] \cdot\left(\mathrm{NO}_{3}\right)_{3} \cdot \mathrm{H}_{2} \mathrm{O}$ & 16 & 6 & 7 & - \\
\hline$\left[\mathrm{Mn}_{2} \mathrm{~L}^{3}\left(\mathrm{H}_{2} \mathrm{O}\right)_{4}\right] \cdot\left(\mathrm{NO}_{3}\right)_{3} \cdot 3 \mathrm{H}_{2} \mathrm{O}$ & 5 & 18 & 8 & - \\
\hline Streptomycin & 22 & 23 & 20 & 23 \\
\hline
\end{tabular}

S. $a .=$ Staphylococcus aureus.

$K . p=$ Klebsiella pneumoniae.

E. $c=$ Escherichia coli.

P. v= Proteus vulgaris.

The complexes $\left[\mathrm{Mn}_{2} \mathrm{~L}^{1}\left(\mathrm{H}_{2} \mathrm{O}\right)_{4}\right] \cdot\left(\mathrm{NO}_{3}\right)_{3} \cdot \mathrm{H}_{2} \mathrm{O},\left[\mathrm{Mn}_{2} \mathrm{~L}^{2}\left(\mathrm{H}_{2} \mathrm{O}\right)_{4}\right] \cdot\left(\mathrm{NO}_{3}\right)_{3} \cdot 1 \frac{1}{2} \mathrm{H}_{2} \mathrm{O}$ and $\left[\mathrm{Mn}_{2} \mathrm{~L}^{3}\left(\mathrm{H}_{2} \mathrm{O}\right)_{4}\right] \cdot\left(\mathrm{NO}_{3}\right)_{3} \cdot 3 \mathrm{H}_{2} \mathrm{O}$ show three decomposition steps. In the first step, the dehydration process takes place in the $30-132,26-100$ and $23-93^{\circ} \mathrm{C}$ range with DTG maxima at 53,67 and $55^{\circ} \mathrm{C}$ with mass loss of $2.8,3.96$ and $7.35 \%$ (calcd. $2.55,3.62$ and $6.95 \%$ ), respectively. DTA confirms this step by endothermic changes at 62,63 and $60^{\circ} \mathrm{C}$, respectively. In the complex $\left[\mathrm{Mn}_{2} \mathrm{HL}^{1}\left(\mathrm{H}_{2} \mathrm{O}\right)_{4}\right] \cdot\left(\mathrm{NO}_{3}\right)_{3} \cdot \mathrm{H}_{2} \mathrm{O}$, elimination of four coordinated water molecules takes place in the $133-192^{\circ} \mathrm{C}$ and $252-392^{\circ} \mathrm{C}$ range with TGA maxima at 154 and $296^{\circ} \mathrm{C}$ associated with mass loss of 4.88 and $4.73 \%$ (calcd. 5.10). DTA shows this step by endothermic and exothermic changes at 132 and $303^{\circ} \mathrm{C}$. This indicates the non-equivalent bonding of the coordinated water. In the complex $\left[\mathrm{Mn}_{2} \mathrm{HL}^{2}\left(\mathrm{H}_{2} \mathrm{O}\right)_{4}\right] \cdot\left(\mathrm{NO}_{3}\right)_{3} \cdot 1 \frac{1}{2} \mathrm{H}_{2} \mathrm{O}$, the coordinated water molecules are eliminated in the second step in the $105-200^{\circ} \mathrm{C}$ range with two DTG maxima at 131 and $187^{\circ} \mathrm{C}$ associated with mass loss of $9.42 \%$ (calcd. 9.66\%). This is shown by endothermic changes in the $118-150$ and $151-239^{\circ} \mathrm{C}$ range with DTA maximum at 137 and $203^{\circ} \mathrm{C}$. Partial decomposition of the ligand and elimination of the nitrate ions as nitric acid begin in the third step in the $201-437^{\circ} \mathrm{C}$ range with two DTG maxima at 294 and $332^{\circ} \mathrm{C}$. This step is accompanied with mass loss of $34.97^{\circ} \mathrm{C}$ (calcd. 35.26) and is confirmed by the appearing of exothermic change in the $240-335^{\circ} \mathrm{C}$ range with DTA maximum at $299^{\circ} \mathrm{C}$. The complex has no plateau at $700{ }^{\circ} \mathrm{C}$ which indicates that it is not completely decomposed. The complex $\left[\mathrm{Mn}_{2} \mathrm{~L}^{3}\left(\mathrm{H}_{2} \mathrm{O}\right)_{4}\right] \cdot\left(\mathrm{NO}_{3}\right)_{3} \cdot 3 \mathrm{H}_{2} \mathrm{O}$ shows the elimination of two nitrate ions as nitric acid and partial decomposition of the ligand in the second step in the $237-320^{\circ} \mathrm{C}$ rang, with maximum at $288^{\circ} \mathrm{C}$ and mass loss of $19.68 \%$ (calcd. $19.43 \%$ ). DTA confirms this step by sharp exothermic change with maximum at $290^{\circ} \mathrm{C}$. In the third step elimination of the coordinated water molecules and a nitrate ion takes place. This process is accompanied with mass loss of $16.95 \%$ (calcd. 17.39\%). The complex has no plateau at $700 \mathrm{C}$ indicating uncompleted decomposition.

Based on the above analytical data and physicochemical properties, the following structures are proposed in which the $\mathrm{Cu}(\mathrm{II})$ ions were coordinated through the carbonyl groups $(\mathrm{C}=\mathrm{O})$ of isatin, the amino groups and the two azomethine nitrogen $\mathrm{C}=\mathrm{N}$ of the aldimine moiety. The $\mathrm{Fe}(\mathrm{III}), \mathrm{Zn}(\mathrm{II})$ and $\mathrm{Mn}(\mathrm{II})$ ions were bonded by the carbonyl groups $(\mathrm{C}=\mathrm{O})$ of isatin, the amino groups, $\mathrm{C}=\mathrm{O}$ or the enolized carbonyl group $(\mathrm{C}-\mathrm{OH})$ of the amide, the azomethine nitrogen $\mathrm{C}=\mathrm{N}$ of the aldimine moiety and the coordinated nitrate or water molecules. 


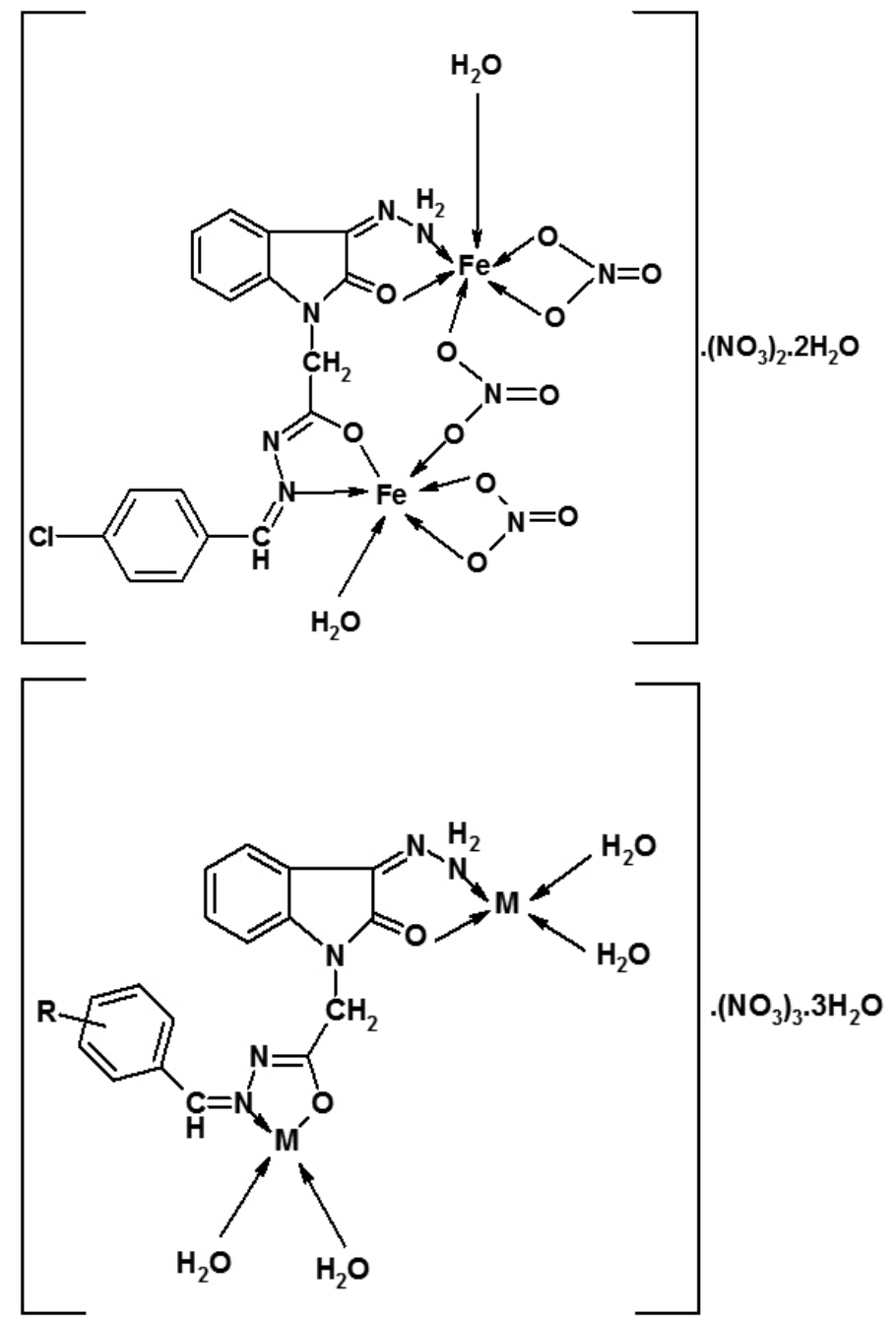

$\mathrm{R}=\mathrm{H}, \mathrm{OCH} 3, \mathrm{Cl} ; \mathrm{M}=\mathrm{Zn}(\mathrm{II})$

$\mathrm{Mn}(\mathrm{II})$

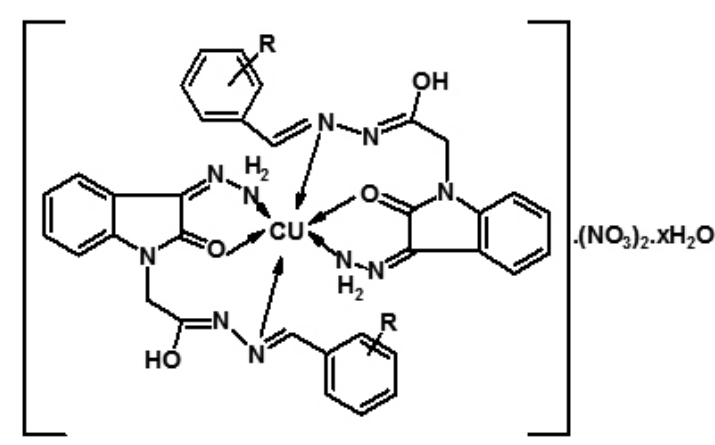

$\mathrm{R}=\mathrm{H} ; \mathrm{x}=5$

$\mathrm{R}=\mathrm{OCH} 3 ; \mathrm{x}=1.5$

$\mathrm{R}=\mathrm{Cl} ; \mathrm{x}=0$

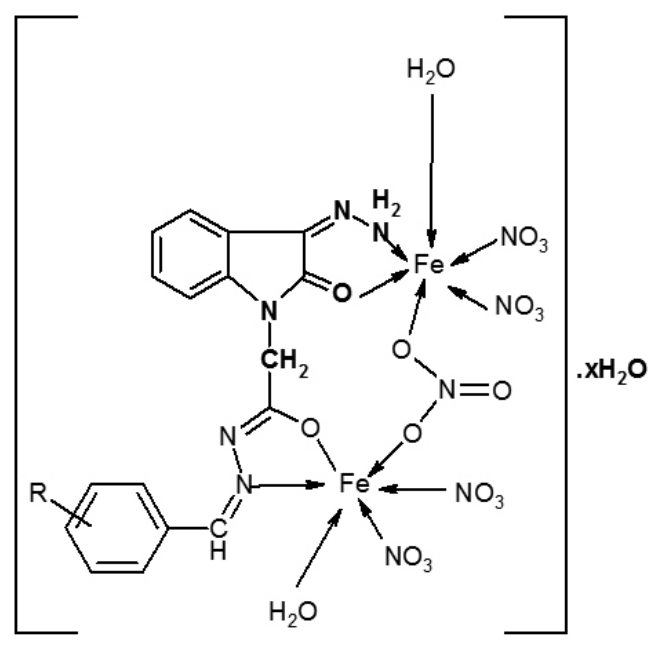

\section{$\mathrm{R}=\mathrm{H} ; \mathrm{x}=4$ \\ $\mathrm{R}=\mathrm{Cl} ; \mathrm{x}=1$}

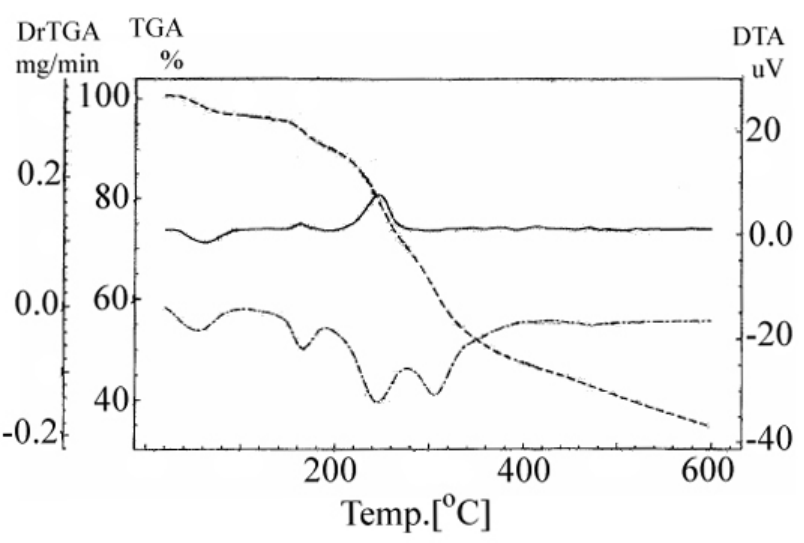

Figure 1. TGA, DTG and DTA of the $\left[\mathrm{CuL}_{2}\right] .\left(\mathrm{NO}_{3}\right)_{2} .5 \mathrm{H}_{2} \mathrm{O}$ complex.

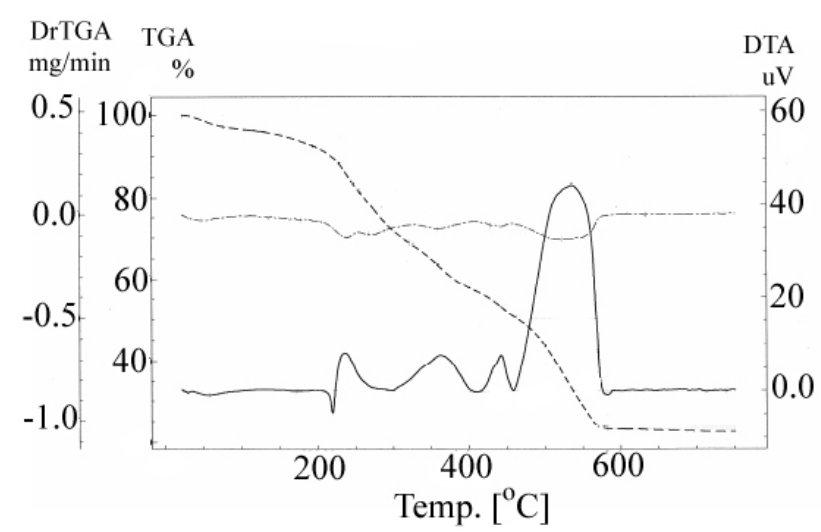

Figure 2. TGA, DTG and DTA of $\left[\mathrm{Fe}_{2} \mathrm{HL}^{2}\left(\mathrm{NO}_{3}\right)_{5}\left(\mathrm{H}_{2} \mathrm{O}\right)_{2}\right] \cdot \mathrm{H}_{2} \mathrm{O}$ complex.

\section{Antibacterial activity}

Antibacterial activity of the synthesized compounds has been screened using different strains of bacteria [Staphylococcus aureus, Klebsiella pneumoniae, Escherichia coli, Proteus vulgaris]. The desk diffusion method has been adapted for antibacterial activity ${ }^{31}$. The results are shown in Table 5 . 
It seems that all the synthesized compounds are devoted of activity against Protus vulgaries while all the compounds are slightly active against Klebsiella pneumoniae and Escherichia coli. $\left(\mathrm{Cu}\left(\mathrm{HL}_{2}\right] .\left(\mathrm{NO}_{3}\right)_{2} \cdot 1 \frac{1}{2} \mathrm{H}_{2} \mathrm{O}\right.$ and $\left[\mathrm{Cu}\left(\mathrm{HL}_{2}\right]\right.$. $\left(\mathrm{NO}_{3}\right)_{2}$ complexes are moderately active against Staphylococcus aureus. $\left[\mathrm{Zn}_{2} \mathrm{HL}^{1}\left(\mathrm{H}_{2} \mathrm{O}\right)_{4}\right] \cdot\left(\mathrm{NO}_{3}\right)_{3} \cdot \mathrm{H}_{2} \mathrm{O}$ and $\left[\mathrm{Zn}_{2} \mathrm{HL}^{2}\left(\mathrm{H}_{2} \mathrm{O}\right)_{4}\right] \cdot\left(\mathrm{NO}_{3}\right)_{3}, 1 / 2 \mathrm{H}_{2} \mathrm{O}$ complexes are inactive against all the studied bacteria while $\left[\mathrm{Zn}_{2} \mathrm{HL}^{3}\left(\mathrm{H}_{2} \mathrm{O}\right)_{4}\right] \cdot\left(\mathrm{NO}_{3}\right)_{3} \cdot \mathrm{H}_{2} \mathrm{O}$ complex is moderately active towards Staphylococcus aureus. $\left[\mathrm{Mn}_{2} \mathrm{HL}^{3}\left(\mathrm{H}_{2} \mathrm{O}\right)_{4}\right]$. $\left(\mathrm{NO}_{3}\right)_{3} \cdot 3 \mathrm{H}_{2} \mathrm{O}$ complex has moderate activity against Klebsiella pneumoniae while $\left[\mathrm{Mn}_{2}^{2} \mathrm{HL}^{1}\left(\mathrm{H}_{2} \mathrm{O}\right)_{4}\right] \cdot\left(\mathrm{NO}_{3}\right)_{3} \cdot \mathrm{H}_{2} \mathrm{O}$ and $\left[\mathrm{Mn}_{2} \mathrm{HL}^{2}\left(\mathrm{H}_{2} \mathrm{O}\right)_{4}\right] \cdot\left(\mathrm{NO}_{3}\right)_{3} \cdot 1 \frac{1}{2} \mathrm{H}_{2} \mathrm{O}$ are slightly active against Staphylococcus aureus. $\left[\mathrm{Fe}_{2} \mathrm{HL}^{1}\left(\mathrm{NO}_{3}\right)_{5}\left(\mathrm{H}_{2} \mathrm{O}\right)_{2}\right] \cdot 4 \mathrm{H}_{2} \mathrm{O}$ and $\left[\mathrm{Fe}_{2} \mathrm{HL}^{2}\left(\mathrm{NO}_{3}\right)_{5}\left(\mathrm{H}_{2} \mathrm{O}\right)_{2}\right] \cdot \mathrm{H}_{2} \mathrm{O}$ are moderately active against Klebsiella pneumoniae and Staphylococcus aureus.

The increased activity of the complexes compared to the free ligands can be explained on the bases of chelation theory ${ }^{32}$. Chelation reduces the polarity of the metal ion; mainly because of the partial sharing of its positive charge with donor groups and the possible $\pi$-electron delocalization over the whole chelate ring. Chelation not only reduces the polarity of metal ion, but also increases the lipophilic character of the chelate. As a result of this, interaction between metal ion and the cell walls is favored resulting in interference with normal cell processes. If the geometry and charge distribution around the molecule are incompatible with the geometry and charge distribution around the pores of the bacterial cell wall, penetration through the wall by the toxic agent cannot take place ${ }^{33}$.

\section{REFERENCES}

1. S. N. Pandeya, D. Sriram, Acta. Pharm. Turc., 40, 33 (1998).

2. M. Sarangapani, V. M. Reddy, Indian J. Heterocycl.Chem., 3, 257 (1994).

3. R. S. Varma, W. L. Nobles, J. Pharm. Sci., 64, 881 (1975).

4. S. K. Sridhar, M. Saravanan, A. Ramesh, Eur. J. Med.Chem., 36, 615 (2001).

5. M. Varma, S, N. Pandeya, K. N. Singh, J. P. Stables, Acta Pharm., 54, 49 (2004).

6. S. N. Pandeya, P. Yogeeswari, D. Sriram, E. De Clercq,

C. Pannecouque, M. Witvrouw, Chemotherapy, 45, 192 (1999)

7. S. N. Pandeya, D. Sriram, G. Nath, E. De Clercq, Eur. J. Med. Chem., 35, 249 (2000).

8. S. N. Pandeya, D. Sriram, G. Nath, E. De Clercq, Arzneim.- Forsch./Drug Res., 50, 55 (2000).

9. S. N. Pandeya, P. Yogeeswari, D. Sriram, G. Nath, Bull. Chim. Farm., 137, 321 (1998).

10. S. N. Pandeya, D. Sriram, G. Nath, E. De Clercq, IL Farmaco, 54, 624 (1999).
11. S. N. Pandeya, D. Sriram, G. Nath, E. De Clercq, Indian J. Pharm. Sci., 61, 358 (1999).

12. S. N. Pandeya, D. Sriram, G. Nath, E. De Clercq, Pharm. Acta Helv., 74, 11 (1999).

13. S. N. Pandeya, D. Sriram, G. Nath, E. De Clercq, Eur. J. Pharm. Sci., 9, 25 (1999).

14. S. P. Singh, S. K. Shukla, L. P. Awasthi, Curr. Sci. 52, 766 (1983).

15. G. Marcu, Chimica complecsilor coordinative; Academiei Bucuresti: Bucharest, 44 (1984).

16. T. Takeuchi, A. Bottcher, C. M. Quezada, M. I. Simon, T. J. Meade, H. B. Gray, J. Am. Chem. Soc., 120, 8555 (1998)

17. G. Cerchiaro, G. A. Micke, M. F. M. Tavares, A. M. D. C. Ferriera, J. Mol. Catal. A: Chem, 221, 29 (2004).

18. A. Bacchi, M. Carcelli, P. Pelagatti, G. Pelizzi, M. C. RodriguezArguelles, D. Rogolino, C. Solinas, F. Zani, J. Inorg. Biochem., 99, 397 (2005).

19. G. Cerchiaro, K. Aquilano, G. Filomeni, G. Rotilio, M. R. Ciriolo, A. M. D. C. Ferriera, J. Inorg. Biochem., 99, 1433 (2005).

20. A.I. Vogel, A Text Book of Quantitative Inorganic Analysis, $4^{\text {th }}$, ed., ELBS, Longman, (1978).

21. W. Geary, Coord. Chem. Rev., 7, 81 (1971).

22. K. Nakamoto, Infrared Spectra of Inorganic and Coordination Compounds, Wiley, New York, (1970).

23. B.M. Gatehouse, S.E. Livingstone, R.S. Nyholm, J. Inorg. Nucl. Chem., 8, 75 (1958).

24. W.E. Estes, J.R. Wasson, J.W. Hass, W.E. Hatfield, Inorg. Chem., 17, 3657 (1978).

25. N.B. Figgis, Nature (1958), 182

26. A.A. Saleh, S.M.E. Khalil, M.F. Eid, M.A. El-Ghamry, J. Coord. Chem., 56, 467 (2003).

27. M.J. Machlachlan, M.K. Park, L.K. Thompson, Inorg. Chem. 35, 5492 (1996).

28. J. Chen, D.Z. Liao, Z.H. Jiang, S.P. Yan, J. Coord. Chem., 58, 1169(2005)

29. A.B.P. Lever, Inorganic Electronic Spectroscopy, $2^{\text {nd }}$ ed., Elsevier, Amsterdam (1984).

30. K.K. Narang, V.P. Singh, Synth. React. Inorg. Met.-Org. Chem., 23, 971 (1993).

31 A.L. Barry and S.D. Brown, J. Clin. Microbiol., 2154 (1996)

32. K.N. Thimmaiah, W.D. Lloyd, G.T. Chandrappa, Inorg. Chim. Acta, 106, $81(1985)$.

33. P. Chakrabarti, J. Mol. Biol., 234, 463 (1993). 